\title{
A Psychology of Ideology: Unpacking the Psychological Structure of Ideological Thinking
}

\author{
Leor Zmigrod ${ }^{1,2}$ \\ Affiliations: $\quad{ }^{1}$ Department of Psychology, University of Cambridge, Cambridge, UK \\ ${ }^{2}$ Behavioural and Clinical Neuroscience Institute, University of Cambridge, \\ Cambridge, UK \\ Contact: $\quad$ Dr Leor Zmigrod, 1z343@cam.ac.uk.
}

This paper has been accepted and is now in press at Perspectives on Psychological Science.

\begin{abstract}
The psychological study of ideology has traditionally emphasized the content of ideological beliefs, guided by questions about what people believe, such as why people believe in omniscient gods or fascist worldviews. This theoretical focus has led to siloed subdisciplines separately dealing with political, religious, moral, and prejudiced attitudes. The fractionation has fostered a neglect of the cognitive structure of ideological worldviews and associated questions about why ideologies - in all their forms - are so compelling to the human mind. It is here argued that it is essential to consider the nature of ideological cognition across a multitude of ideologies. The review offers a multidimensional, empirically-tractable framework of ideological thinking, suggesting it can be conceptualized as a style of thinking that is rigid in its adherence to a doctrine and resistance to evidence-based belief-updating, and favourably-oriented towards an ingroup and antagonistic to outgroups. The review identifies the subcomponents of ideological thinking and highlights that ideological thinking constitutes a meaningful psychological phenomenon that merits direct scholarly investigation and analysis. By emphasizing conceptual precision, methodological directions, and interdisciplinary integration across the political and cognitive sciences, the review illustrates the potential of this framework as a catalyst for developing a rigorous domain-general psychology of ideology.
\end{abstract}




\section{CONTENTS}

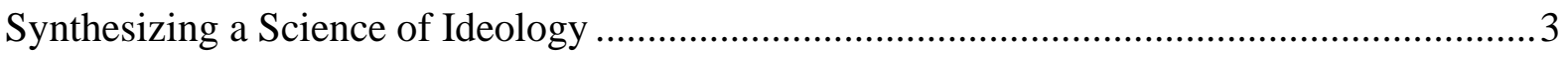

The History of Demarcating Ideology ............................................................................

The Psychological Structure of Ideological Thinking: Domain-General Components .............8

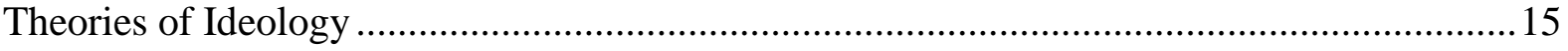

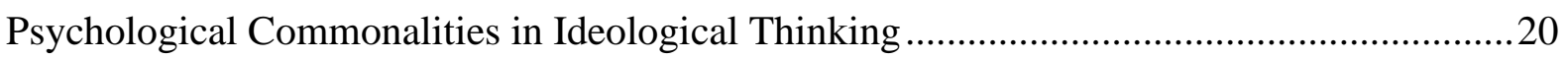

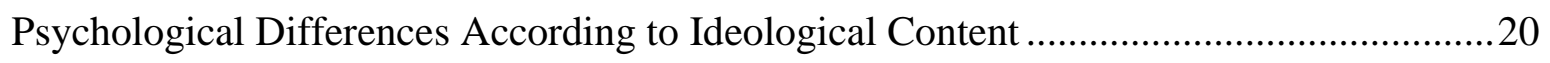

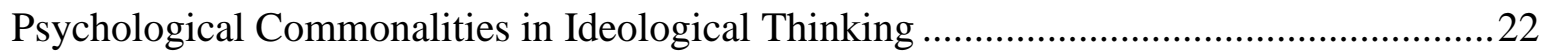

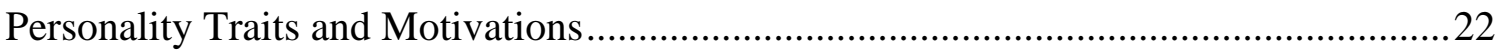

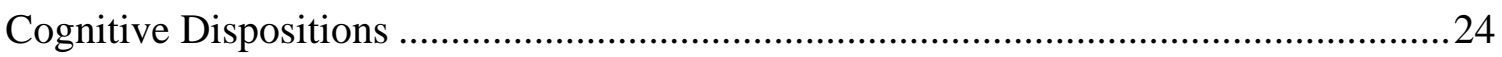

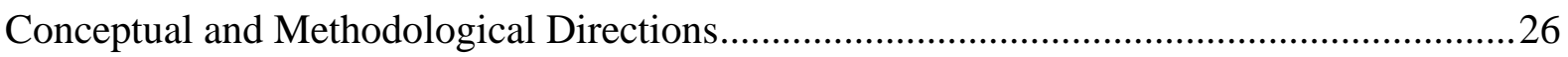

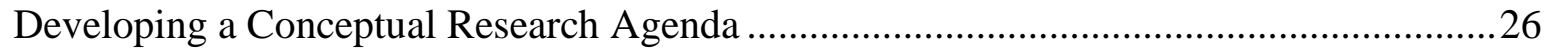

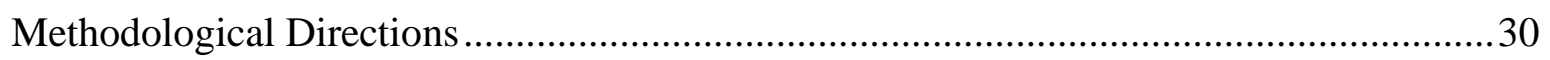

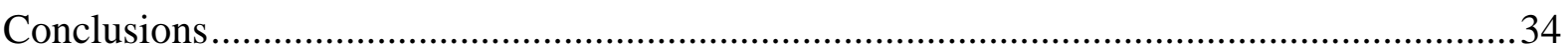


"Belief systems have never surrendered easily to empirical study or quantification. Indeed, they have often served as primary exhibits for the doctrine that what is important to study cannot be measured and that what can be measured is not important to study."

- Philip Converse (1964, p.1), The Nature of Belief Systems in Mass Publics

\section{Synthesizing a Science of Ideology}

Since the birth of modern civilization, human beings have been creating stories that capture their theories about how the world works and how they should act within this complex world. These narratives both describe and prescribe human action, and exist in a kaleidoscope of forms - from religious doctrines to political manifestos, and from racial supremacy to authoritarian nationalism. These accounts are broadly termed "ideologies", and envelope humans' personal and social lives to a considerable degree. The Pew Research Centre estimates that $84.4 \%$ of people affiliate with a religious institution ${ }^{1}$, and the International Institute for Democracy and Electoral Assistance approximates that over 1.3 billion people voted in their local parliamentary elections across the world between 2016 and $2019^{2}$. Exposure to and participation in collective ideologies is therefore remarkably prevalent and consequential to people's daily lives.

How should "ideology" be defined? Political theorists, sociologists, and psychologists have espoused (at times radically) different conceptualizations of ideology. Definitions have ranged from the general (e.g. Adorno et al., 1950; Converse, 1964) to the particular (e.g. Platt \& Williams, 2002). As a starting point, most contemporary definitions of ideology have recognized that an ideology functions as a force that epistemically organizes beliefs about

\footnotetext{
${ }^{1}$ Data can be found at:

http://globalreligiousfutures.org/explorer\#/?subtopic=15\&chartType=pie\&year=2020\&data_type=percentage \&religious_affi liation $=$ all $\&$ destination $=$ to $\&$ countries $=$ Worldwide $\&$ age_group $=$ all $\&$ gender $=$ all $\&$ pdfMode $=$ false

${ }^{2}$ Data can be found at: https://www.idea.int/data-tools/question-view/441
} 
how society ought to be structured (Adorno et al., 1950; Campbell et al., 1960; Kerlinger, 1984) and how people ought to behave. It provides "both an interpretation of the environment and a prescription as to how that environment should be structured" (Denzau \& North, 1994, p. 24, emphasis added). Ideologies also operate as forces that socially organize communities, such as tribes, classes, constituencies, and societies (Freeden, 2001; Knight, 2006; Van Dijk, 2006). While there is variability in the specific definitions of ideology, there is a general consensus amongst scholars that ideologies are epistemically and socially organizing forces.

This review seeks to make three central claims about the study of ideology with the aim of building a robust science of ideological thinking. Firstly, the term "ideology" has been used in different ways by scholars from the disciplines of politics, sociology, and psychology, and this had led to challenges in distinguishing between psychological and non-psychological processes in the realm of ideologies. Secondly, whenever psychologists have investigated the nature of ideological beliefs, they have been largely guided by a theoretical interest in the content of ideological beliefs rather than the structure of ideological thinking. In other words, researchers have focused on asking why individuals believe specific ideological claims (such as about the presence of omniscient gods or socialist worldviews), rather than why ideological attitudes - regardless of their content - are so compelling to the human mind and pervasive across civilizations. The focus on ideological content has also obscured critical questions about why some individuals are more attracted to ideological doctrines than others. Nonetheless, there are notable structural and psychological commonalities across diverse ideologies, and so it is possible to advance a psychology of ideology that is attuned to the cognitive structure of ideological thinking across a multitude of ideological domains. Lastly, the review will build on these observations to formulate a framework of ideological thinking that posits domain-general components and tractable research questions. Methodologically, 
this endeavour involves examining the psychological substrates of ideologies that may seem radically different and even opposing in objectives, under unified empirical investigations. This structure-oriented approach does not negate content-focused approaches, but the structure-based perspective can illuminate relationships that have been hitherto unexamined.

In sum, this proposal for an integrated psychology of ideology aims to catalyse interdisciplinary synthesis regarding what it means for ideological scripts to be internalized by the human mind and how the fundamental mechanisms of cognition shape the ideologies that we endorse and evangelize. It also seeks to demonstrate how we can diagnose thought patterns (and individuals, and perhaps communities or societies) that are strongly ideological from those that are weakly so, or not at all. A science that tackles the commonalities between diverse ideologies can facilitate a more conceptually and methodologically mature psychology of ideology.

\section{The History of Demarcating Ideology}

Historically, there have been continual changes in the available and predominant ideologies. Correspondingly, there have been shifts in what has been considered an ideology. Perhaps the earliest manifestations of ideologies are evident in folk myths; these narratives theorized about the causal structure of the world, imagining unseen agents that were responsible for objects and occurrences in the observable world (Atran, 2002; Norenzayan, 2013). Myths were elaborated upon by organized religions in order to legitimize and dictate certain forms of personal and social behaviour. This was followed (in a historical sequence that is neither linear nor uncontested) by the emergence of "secular religions" in the form of sacralised political action and organization. It was at this point in the development of contemporary political life that the term "ideology" entered common usage, and so ideology is often synonymized with political ideology (Freeden, Sargent, \& Stears, 2013). But viewing 
history through a broad lens reveals that the ideologies that have governed the human story have in fact shifted and oscillated between mythical, religious, and secular-political forms.

The term "ideology" was coined during the French Revolution by French "ideologues" who wished "to label a new science outlined in the framework of the Enlightenment programme, the teaching of ideas" (Stråth, 2013, p. 16) - ideology was therefore originally meant to reflect a new science of ideas. Nonetheless, the expression was quickly politicized during Napoleon's reign and became synonymous with “unrealistic theories that tried to intervene in the spheres of government and political action” (Stråth, 2013, p. 20). By the mid- $20^{\text {th }}$ century - following the rise and fall of several totalitarian ideologies - "ideology" was re-imbued with a sense of systematicity: ideologies were conceptualized as long, coherent chains of thought that served as instruments for managing societies and negotiating social and political power. This conceptualization is also mirrored in the exponential rise in the usage of the term "ideology" between 1940 and the 1970s (see Figure 1). Contemporary definitions of ideology typically deal with the latter political interpretation, as this has emerged most recently on the world stage and rapidly modified social relations and traditional power hierarchies. Since then, much ink has been spilled over whether ideology should be defined in a value-neutral fashion or whether to espouse positive or pejorative definitions. Notably, the use of the word ideology itself has experienced a steep decline since the late 1990 s - perhaps as a response to the worry that it is an ambiguous and historically-contested term (Corner, 2001; Rorty, 1993). 


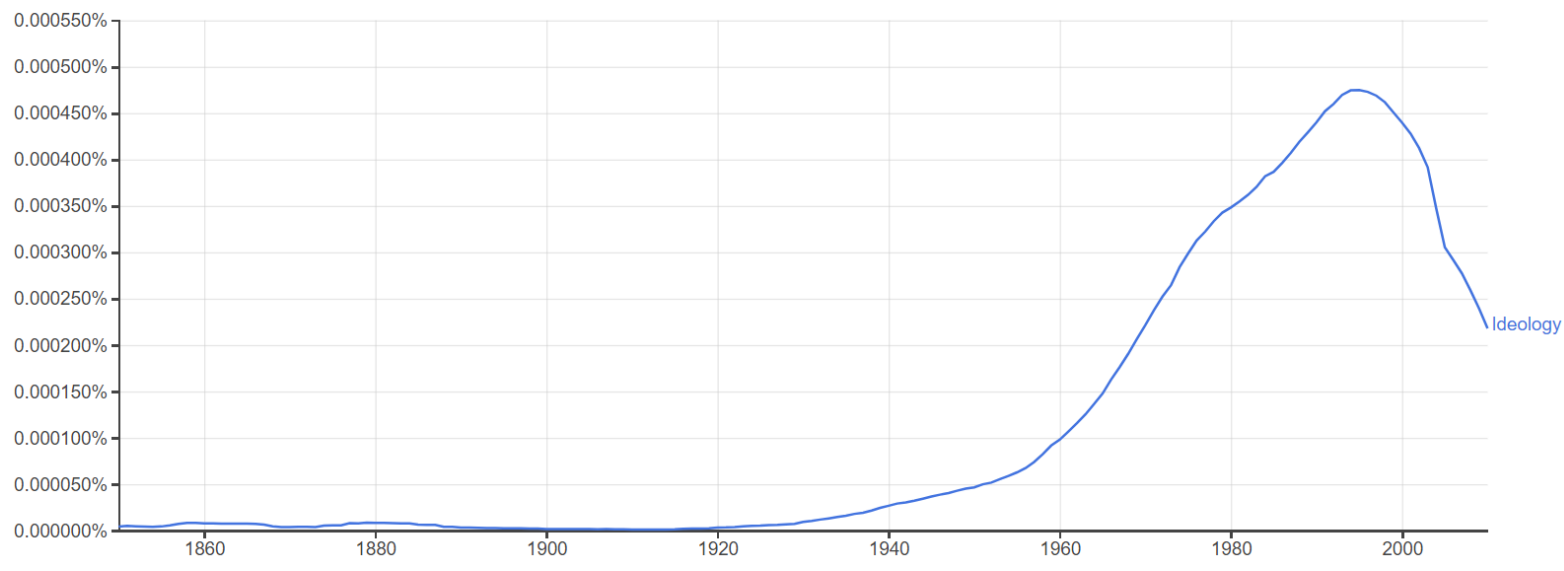

Figure 1. Frequency of the term "Ideology" in English books between 1850 to 2010 according to Google Books Ngram Viewer. Y-axis reflects percentage of single-word phrases in English GoogleBooks that are equal to "Ideology". Frequency peaks in 1993.

Some scholars have considered ideology to be a necessary aspect of social cohesion (e.g. the functionalist structuralists, as reviewed by Malešević, 2006) while others have viewed ideologies as mechanisms for distorting reality to satisfy the interests of the few and to induce "false-consciousness thinking" (Dant, 1991; Marx \& Engels, 1939; Williams 1977; Mannheim, 1936; Habermas, 1989). These definitions have changed over time in response to historical events such as the Holocaust and the dismembering of the Soviet Union, as well as landmark disciplinary proposals and critiques $^{3}$ (see Figure 1). While comprehensive reviews of the concept of ideology in different subdisciplines can be found elsewhere (e.g. Jost et al., 2008 in psychology; Malešević, 2006 in sociology), here we will broadly synthesize these definitions in order to delineate a phenomenon that is more specific than merely a "system of beliefs" (Converse, 1964) and scientifically-clearer than a "universal and complex social process through which human actors articulate their actions and beliefs" (Malešević, 2011). A primary aim will be to identify a tractable conceptualization of ideology that is applicable

\footnotetext{
${ }^{3}$ Such as the effect of Adorno and colleagues' (1950) The Authoritarian Personality on social psychology, the effect of The American Voter by Campbell and colleagues (1960) on political science, and the poststructuralist critique of the concept of ideology in sociology
} 
both to political ideologies (commonly conceptualized along a left-to-right political spectrum) as well as ideologies that are not explicitly about political organization (e.g. religious, environmental, nationalistic, patriarchical, etc.). This approach will facilitate the building of models of ideology that are informative across diverse cultural and historical contexts and that achieve greater precision in delineating the mechanisms by which ideologies serve as epistemic and social organizational forces.

\section{The Psychological Structure of Ideological Thinking: Domain-}

\section{General Components}

Psychologists have far from neglected ideologies: in fact, rich lines of inquiry in social psychology have sought to unpack the complex processes by which individuals form ideological beliefs. Nonetheless, the study of ideology is marked by substantial balkanization. There is now a psychology of politics (Jost et al., 2003a), of religion (Norenzayan, 2013), of nationalism (Anderson, 1983; Billig, 1995), of prejudice (Brandt, 2017; Dovidio, Hewstone, Glick, \& Esses, 2010; Duckitt \& Sibley, 2009), of dehumanization (Haslam, 2006), of obedience (Haslam \& Reicher, 2007; Reicher \& Haslam, 2011), of collective action (van Zomeren, Postmes, \& Spears, 2008), of moralization (Rhee, Schein, \& Bastian, 2019; Rozin, 1999), of conspiracy theories (Douglas, Sutton, \& Cichocka, 2017; van Prooijen \& Van Vugt, 2018), of radicalization (Kruglanski et al., 2014) - but there isn't an overarching psychology of ideology.

The reasons for this fractionation are historical, methodological, and conceptual, and perhaps all can be traced to a theoretical interest in the content of ideological beliefs rather than the structure of ideological thinking. Psychologists have concentrated on the frequency, prevalence, and popularity of specific ideological claims (e.g. political conservatism or supernatural beliefs), rather than why ideological attitudes - regardless of their content - so 
powerfully captivate the human imagination. An emphasis on the content of ideological beliefs justifies the existing academic landscape, in which each ideological domain merits its own discipline of study. In contrast, a theoretical and empirical focus on the systematic processes of ideological immersion invites a wholistic, interdisciplinary outlook that addresses the commonalities across diverse ideologies.

Indeed, a striking - and often understated - observation made by social scientists and theorists is that diverse, and sometimes opposing, ideologies use remarkably similar tools and mechanisms to inculcate their followers and galvanize them towards collective action and self-sacrifice (Hoffer, 1951). In particular, ideologies possess two essential qualities regardless of the content of their beliefs or ambition: they are doctrinal and relational. Each of these two characteristics corresponds to particular means of ideological indoctrination.

Firstly, the doctrinal component of ideologies is facilitated by the existence of a rigid dogma that the ideology embraces. This dogma assumes the existence of one true explanation of - and corresponding solution to - existing societal (and often personal) conditions. Dogmas frequently possess a compelling logic, if the premises are believed (Arendt, 1951), and tend to enforce a sharp distinction between those in possession of the ideology's truth and those who are not. Dogmas also typically espouse categorical divisions between what constitutes "good" versus "evil" and who belongs to the ideological ingroup ("us") and who does not ("them"). As sociologist Edward Shils suggested in 1958, "the belief of those who practice politics ideologically [is] that they alone have the truth about the right ordering of life - of life as a whole, and not just of political life" (Shils, 1958, p. 451, emphasis added). Ideologies thus breed rigidity and dogmatism about truth, morality, and identity.

Secondly, the relational facet of ideologies - characterized by parochial altruism towards fellow adherents and antagonism towards non-adherents and dissimilar others - is 
facilitated by processes of identity demarcation. All ideologies invent and adopt clear identity markers, such as flags, symbols, anthems, costumes, and rituals, which signal membership and devotion. Examples are rife in nationalistic flags and dress, religious and spiritual rituals, political parties' and movements' association with specific symbols and hand gestures, and sports teams' songs and colours (e.g. DeMarrais et al., 1996; Fominaya, 2018; Wiltgren, 2013). The shared, visible, and physical nature of these identity markers fosters passionate feelings of immersion and connectedness with the ideological group. Indeed, people are often prepared to kill and die over a flag or a defaced ideological symbol that represents their group (Whitehouse et al., 2014; Swann et al., 2010a, 2010b). Crucially, these identity markers also signal who is not a member of one's ideological group, or who is a weakly committed member. Symbolic gestures and rituals therefore serve as practical and tangible criteria for interpersonal behaviour and the perceived legitimacy of collective action.

These common tools of ideological indoctrination - rigid dogma and identity markers - can be found consistently across the spectrum of ideological persuasions ${ }^{\mathrm{i}}$. From fascism and communism to radical eco-activism and religious evangelism, ideological groups offer absolute answers to societal troubles, strict rules for behaviour, and an ingroup mentality through dedicated practices and symbols. These mechanisms are further amplified by propaganda (Holbig, 2013) and systems of punishment for deviance and disbelief (Boyd, Gintis, Bowles, \& Richerson, 2003; Fehr \& Gachter, 2002). They are also often augmented via the use of familial and kinship metaphors that depict fellow comrades as "sisters and brothers-in-arms", religious leaders as "mothers and fathers", the nation as the "motherland" or "fatherland", and revolutionaries as the "sons and daughters" of ideological causes (Whitehouse \& Lanman, 2014; Malešević, 2011, p. 287). These characteristics emerge even when the ideology is guided by sincere or benevolent intentions and ideals, and allow 
ideologies to endow followers with a sense of coherence, belonging, meaning, and identity that is tightly intertwined with their attachment to the ideological group (Malešević, 2011).

Consequently, an ideology, as defined and evaluated here, possesses two characteristics. Firstly, it has a doctrinal component, reflected in a doctrine composed of a set of descriptive and prescriptive attitudes about social relations and norms. In other words, an ideology interprets the world and offers prescriptions for how people ought to think, behave, and interact. The doctrine is fixed and resilient in the face of reliable but opposing evidence. Secondly, because there will be adherents and non-adherents to the doctrine's prescriptions, an ideology entails a relational component, in which there is strong ingroup favouritism towards other adherents of the ideology coupled with distrust towards outgroups ${ }^{\mathrm{ii}}$. These structural components of ideologies can translate into the psychological realm: "Ideological thinking" can therefore be defined as a style of thinking that is rigid in its adherence to a doctrine and resistance to evidence-based belief-updating (i.e. doctrinal), and favourably oriented towards an ingroup and antagonistic to outgroups (i.e. selectively relational) ${ }^{4}$.

This definition posits that individuals vary in the extent to which they display ideological thinking, depending on how epistemically dogmatic and interpersonally intolerant they are towards those who do not belong to their ideological group. It is thus possible to envision a spectrum whereby some individuals are ideologically extreme, in which case they are rigidly espousing a doctrine and willing to harm others and incur personal costs (such as self-sacrifice) in the name of the ideology, and others are ideologically moderate and so are receptive to credible evidence and display tolerance for those they disagree with. There are therefore gradations from ideological extremism to moderation. Notably, this definition of ideological thinking is agnostic as to (a) whether the ideology possesses logical coherence

\footnotetext{
${ }^{4}$ Importantly, throughout the review, the term "ideological" refers both to the property of being associated with an ideological doctrine (in the traditional sense) and to the property of having the doctrinal and relational characteristics of ideologies as defined here.
} 
and systematicity, (b) whether it reflects or captures objective truth, (c) whether it has a reality-distortion function, and (d) the extent to which the ideology is purely symbolic or practical. This framework is also agnostic with regards to the ideology's content - it can be religious, political, or secular. Instead, it emphasizes the structure and style of thinking that ideologies inculcate in followers.

In order to synthesize a robust and fruitful science of ideology, it is essential to decide on empirically useful definitions of ideological thinking. As outlined above, ideological thinking can be described as a style of thinking that is rigid in its adherence to a doctrine and resistance to evidence-based belief-updating (i.e. doctrinal), and favourably oriented towards an ingroup and antagonistic to outgroups (i.e. selectively relational). Ideological thinking is therefore not purely dogmatism or simply intergroup attitudes - ideological thinking is a phenomenon that intertwines both. Based on the rich literature on political cognition, we can break this down further into tractable subcomponents (see Figure 2). The doctrinal component involves the embrace of a rigid dogma, and consequently the adoption of (1) an absolutist description of the present and past as well as (2) a set of prescriptions for future thought and behaviour. Indeed, cognitive research reveals that mental representations of what is are separable and yet bound up with what can be (Philips \& Cushman, 2017; Philips \& Knobe, 2018; Philips, Morris, \& Cushman, 2019; Shtulman \& Tong, 2013) and this begins in infancy (Shtulman \& Philips, 2018), and so the brain processes descriptions and prescriptions of thought and actions in an intertwined yet distinct fashion. Synthesizing the social psychological literature, it can be posited that the relational component of ideologies, in which ingroup and outgroup members are demarcated, involves (1) strong personal identification with the ingroup and (2) a rejection of non-adherents that often takes the form of hostility and prejudice. This relational component mirrors the substantial literature in psychology on self-categorization and social identity theory (Tajfel \& Turner, 1979; Turner, 
Hogg, Oakes, Reicher, \& Wetherell, 1987) which illustrate how conceptions of the self are integrated with ideas about similar and dissimilar others. The level of identification with the group shapes the level of hostility and prejudice, but the relationship between them is dependent on context (e.g. Jasko et al., 2019) and individual differences (e.g. Hogg, 2005).

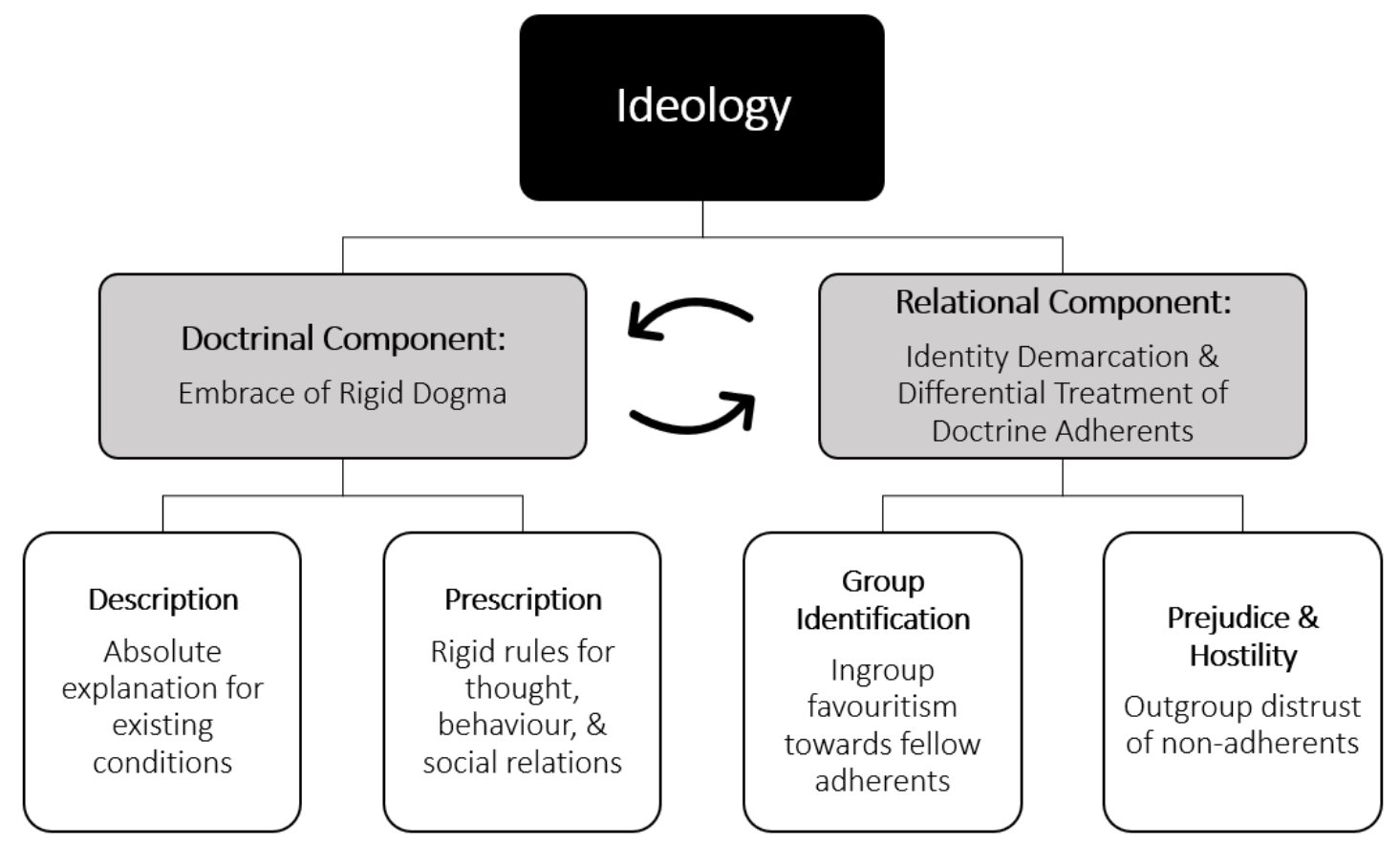

Figure 2. The components and subcomponents of ideology - which are consequently psychologically reflected in ideological thinking.

Using this taxonomy, we can identify ideologies and ideological thinking based on the structure of ideological cognition, and not only on the content of the doctrine. This structureoriented approach does not deny the importance of content, but it can elucidate unexplored research questions. It can therefore expand existing knowledge into a more comprehensive theory of ideology. The four subcomponents (outlined in Figure 2) are all necessary and jointly-sufficient for ideological thinking (and especially ideological extremism) to emerge in the full sense. Rather than purely focusing on whether the ideology deals with questions of political organisation, social hierarchies, religious beliefs, environmental protection, or class 
struggles, the proposed approach implies that we can separate thought patterns that are strongly ideological from those that are weakly so, or not at all. For example, an ideologically extreme individual is one who (a) possesses a rigid, evidence-resistant description of the world, (b) strongly adheres to inflexible prescriptions for how they and others ought to live and act, (c) exhibits intense identification with fellow adherents, and (d) displays active hostility towards non-adherents. In contrast, an ideologically moderate individual is one who (a) adopts a description of the world that is flexible and responsive to evidence, (b) does not rely on or impose on others rigid prescriptive rules for living, (c) displays weak or moderate identification with others who believe in similar worldviews, and (d) does not express hostility or prejudice towards dissimilar others. Consequently, the question of whether the ideologies of these two individuals concern race, gender, class, climate change, religion, or politics is irrelevant as to whether they can be designated as ideologically extreme or moderate.

Can ideological thinking be reduced to mere dogmatism? In other words, can ideologies consist purely of doctrines without relational identities? Such "isms" certainly exist, such as free market capitalism or neoliberalism, but they may not be of genuine psychological interest. Political, historical, or sociological analyses are better suited for ideologies which do not engender in individuals some kind of ingroup identification and the potential for outgroup derogation. For psychological and cognitive scientists, the ideological phenomena that warrant investigation are those that can breed intergroup intolerance and hostility. Consequently, even ideologies such as veganism or environmentalism can produce ideological thinking for some people because individuals can be both epistemically dogmatic about these ideologies and to treat non-adherents with contempt, suspicion, and sometimes violence. Not all individuals who adhere to these ideologies will be dogmatic or intolerant, 
but some individuals will be - and it is the difference between these two groups that can yield fascinating lines of research for the psychology of ideology.

"Isms" built around openness and tolerance may thus not always fulfil the criteria for provoking ideological thinking. The framework presented here can therefore be used to diagnose ideologies and individuals which are particularly dangerous - when they breed evidence-resistant dogmatism and intergroup intolerance - and those which are less toxic. Focusing on the structure of the ideology rather than its content can hence shed light on key processes that were previously obscured due to historical use of the term "ideologies" to refer to a wide variety of phenomena.

\section{Theories of Ideology}

In order to situate this account within broader research on ideologies - and to highlight its novelty and significance - it is valuable to differentiate the phenomenon of ideological thinking outlined here from past or existing theories of ideology and related constructs. Between the 1960 s to the 1980 s, political scientists largely defined a person who is "ideological" as one who possesses a coherent and stable belief system (Jost, 2006; Friedman, 2006) and so many political scientists debated the extent to which ordinary citizens are capable of being ideological - that is, of possessing coherent, articulable, and noncontradictory political beliefs (Kerlinger, 1984; Campbell et al., 1960; Converse, 1964; Judd \& Milburn, 1980; Tedin, 1987). The framework presented here is not concerned with individuals' capacity to be ideologically sophisticated or systematic: it begins from the premise that all individuals engage with ideologies to differing degrees, and interesting empirical questions arise when we consider why some engage with pre-packaged belief systems in a strong and passionate way, while others do not. 
In sociology, ideology has typically been evaluated in relation to systems of power, legitimacy, and collective imagination (Kumar, 2006), especially in the context of capitalism, religion, fascism, and the production of knowledge (Hall, 1977). For an individual to be "ideological" in the sociological sense, they are defined as having simplified, reduced, and distorted a complex social reality; ideology is in an antagonistic tension with truth and science (Vincent, 2010). Other accounts that seek to link the sociological and philosophical critique of ideology with political concerns have posited that "what makes political thinking ideological relates to the linguistic need and interpretative imperative to choose among contested meanings of concepts, in order to attain the control over language that renders collective political action possible" (Freeden, 2003). The problem with these broad truth- and action-oriented accounts of ideology is that they do not lend themselves easily to psychological analysis or theory. These theories struggle to ask (and answer) why and how a particular mind comes to adopt ideologies fervently. In contrast, when we consider ideological thinking as reflecting a combination of epistemic dogmatism and interpersonal intolerance, we are working with concrete psychological phenomena that can be put under an empirical microscope and tested in a range of ideological contexts.

Within psychology itself, ideology - the infamously slippery construct - has often been synonymized with "belief system", "worldview", "social attitudes", "values", "culture", "life philosophy", or "political orientation". It is useful to briefly review how these terms relate to ideology, as conceptualized here. Koltko-Rivera (2004) viewed worldviews as sets of beliefs and assumptions that describe reality. Following a qualitative and historical review, Koltko-Rivera (2004) listed an extensive number of topics for worldview beliefs, such as worldviews on morality, agency, interpersonal justice, authority, humanity, and more. Although valuable and widely-appreciated, Koltko-Rivera's model of worldviews includes over 40 possible worldview topics, and so struggles to delineate tractable phenomena that can 
be of easy use to the psychologist of ideologies. Saucier $(2000,2013)$ adopted a more empirical approach, relying on factor-analysis of dictionary-derived questionnaire items to evaluate the structure of terms that end in -ism, such as liberalism, nationalism, ethnocentrism, fundamentalism, individualism, spiritualism, and others. This resulted in five dimensions that capture such -isms, which Saucier labelled Tradition-oriented Religiousness, Subjective Spirituality, Unmitigated Self-Interest, Communal Rationalism, and InequalityAversion (Saucier, 2013). These dimensions, especially Tradition-oriented Religiousness and Inequality-Aversion, were related to two ideological orientations that constitute Duckitt and Sibley’s (2001, 2009a, 2009b, 2010) Dual-Process Motivational Model: Right-Wing Authoritarianism (RWA) and Social Dominance Orientation (SDO). The Dual-Process Motivational (DPM) Model moves away from unidimensional accounts of ideology that emphasize a single left-right political spectrum (e.g. Adorno et al., 1950; Jost et al., 2003), and instead proposes that RWA and SDO are two distinct ideological dimensions which express separable psychological and motivational processes and traits. According to the DPM account, individuals who score highly on RWA are motivated to establish collective security in response to threats, while those who are high in SDO are concerned with establishing group dominance and superiority. The utility of the DPM approach is clear and has been applied to various ideological outcomes such as prejudice (Cichock, Dhont, Makwana, \& Back, 2017), anti-gay (Moor, Kapelles, Koc, \& Anderson, 2019) and anti-vegan attitudes (Judge \& Wilson, 2018), immigration attitudes and post-colonial ideology in New Zealand (Satherley \& Sibley, 2016, 2018), as well as the evolution of political ideology (Claessens, Fischer, Chaudhuri, Sibley, \& Atkinson, 2020). The authoritarian aggression element of the DPM evaluates hostility towards individuals perceived to be dissident to endorsed authorities or deviant from embraced social conventions (Mavor et al., 2010) and so this line of research can help productively inform research on the relational components of ideological thinking. 
Nonetheless, the locus of the intergroup dynamic in the DPM approach is about how individuals view social structures rather than how they treat others who share or deviate from their ideology: there is little attention to how individuals treat adherents vs non-adherents (as in the relational component suggested here) or how dogmatically they adhere to these authoritarian or hierarchical ideologies (as in the doctrinal component). The present framework on ideological thinking therefore fills a gap in existing theories of the components of ideologies but also speaks collaboratively to such accounts.

Another set of theories that focus on the motivational origins of ideologies, and consider ideologies in a fairly general way, are significance quest theory (SQT; Kruglanski et al., 2014), uncertainty identity theory (UIT; Hogg et al., 2014), and terror management theory (TMT; Greenberg \& Arndt, 2011). Each posits that individuals adhere to ideologies in order to satisfy needs to achieve meaning (SQT), certainty (UIT), and a sense of endurance and esteem in the face of mortality (TMT). The present framework can be compatible with - and help expand - these theories by providing greater specificity about the nature of ideological thinking and by identifying structural cognitive features of ideologies - and not only the motivations they satisfy - that make some brains more susceptible to ideological thinking than others. What aspects of achieving meaning or certainty push individuals towards epistemic dogmatism? And which contribute towards interpersonal intolerance? An integrated account of ideological thinking will support a more mechanistic approach to these motivational theories.

If we examine research on racism, nationalism, sexism, religion, and other ideologies, we can detect how doctrinal and relational components are evident repeatedly within these diverse ideologies. In the context of racism, Jones (2000) defined personally-mediated racism as consisting of adherence to racist beliefs and assumptions about the links between race, biology, and ability as well as differential treatment of others in accordance with this racist 
ideology (Trawalter, Bart-Plange, \& Hoffman, 2020). The doctrinal and relational components thus reappear in the context of racist ideologies. Likewise, prominent theorists of nationalism (Blank \& Schmidt, 2003; Feschbach, 1994; Kosternman \& Feshbach, 1989; Virloi, 1995) defined it in terms of a doctrine of national superiority, dominance, and militarism combined with positive ingroup regard and hostile outgroup treatment, implicitly echoing the doctrinal and relational features. Furthermore research on gender ideologies highlight how it encompasses a non-egalitarian ideology which assumes binary gender roles based on essential biological differences (i.e. the doctrine) and malicious treatment of individuals who deviate from the expectations of this doctrine (Glick \& Fiske, 2001; Hammond, Sibley, \& Overall, 2013; Saguy et al., 2021). Similarly, in a comprehensive account of the cognitive dynamics of religion (Barrett, 2007), Whitehouse $(2000,2004)$ proposed that religiosity can cluster into two distinct modes: "doctrinal" and "imagistic" modes. In the doctrinal mode, religion focuses on transmitting and retaining highly complex bodies of knowledge (e.g. through theological texts and teaching). In the imagistic mode, religion takes the form of highly emotionally arousing events and rituals that provoke feelings of interpersonal connection and oneness. These modes, empirically corroborated through anthropological research (Whitehouse, 2002; Whitehouse \& Martin, 2004; Whitehouse \& McCauley, 2005), map on nicely to the psychological framework presented here, which emphasizes ideologies' doctrinal components on one hand and relational features on the other. Thus, even a cursory view of a range of ideologies reveals that both doctrinal and relational features characterize the psychological structure of ideologies, reappearing in multiple guises that can be analysed in a content-free fashion. 


\section{Psychological Commonalities in Ideological Thinking}

\section{Psychological Differences According to Ideological Content}

As noted earlier, psychological research on ideologies has largely focused on the discrepant content of ideologies, rather than the commonalities in the cognitive style these can impose on followers. As a result, the most popular experimental design has examined individuals who identify with the mission of a particular ideology and compared them with those who self-identify with the opposing ideology. In political psychology, this has taken the form of methodological comparisons between self-identified political conservatives and liberals. In other social psychology subfields, this approach is featured in the comparison between religious and atheist individuals or between racist and non-racist individuals.

Content-based comparisons have yielded a profound theoretical and empirical debate between researchers who identify psychological differences between right-wing and left-wing individuals (e.g. Baron \& Jost, 2019; Jost et al., 2003; Jost, 2017; Hibbing et al., 2014;

Nilsson \& Jost, 2020), and researchers who challenge the widely-held assumption that such differences exist (e.g. Bakker, Schumacher, Gothreau, \& Arceneaux, 2020; Brandt, Reyna, Chambers, Crawford, \& Wetherwell, 2014; Crawford, 2017; Crawford \& Brandt, 2019, 2020; Crawford \& Pilanski, 2014; Ditto et al., 2019; Frimer, Skitka, \& Motyl, 2017; Greenberg \& Jonas, 2003). The findings from the political psychology literature have illustrated that direct comparisons of right-wing versus left-wing participants do generally reveal psychological differences in personality, motivations, values, and cognition. For instance, research on the personality and motivations of political conservatives and liberals in the US has shown that conservatives tend to self-report a greater need for closure, structure, order, certainty, and absence of ambiguity (meta-analysis by Jost, Sterling, \& Stern, 2018; see also: Carney, Jost, Gosling, \& Potter, 2008; Gerber et al., 2010; Jost, 2017; Jost, Federico, \& Napier, 2009). Political liberals, on the other hand, report a more favourable attitude towards science (Blank 
\& Shaw, 2015; Lewandowsky \& Oberauer, 2016; Tullett, Hart, Feinberg, Fetterman, \& Gottlieb, 2016; but also see: Washburn \& Skitka, 2018) and tend to perform better on tests of cognitive ability (Choma \& Hanoch, 2017; Deary, Batty, \& Gale, 2008; Eidelman, Crandall, Goodman \& Blanchar, 2012; Heaven, Ciarrochi, \& Leeson, 2011; Hodson \& Busseri, 2012; Onraet et al., 2015; Yilmaz \& Saribay, 2017). Political liberals are also more resistant to conspiracies or misinformation (Jost, van der Linden, Panagopoulos, \& Hardin, 2018; Miller, Saunders, \& Farhart, 2016; Pennycook \& Rand, 2020; Pfattheicher, \& Schindler, 2016; Sterling, Jost, \& Pennycook, 2016). Further research into values and moral foundations has suggested that political conservatives adopt more "binding" values such as sanctity, authority, and loyalty, while political liberals value more "individualizing" forms of morality that emphasize fairness and care (Graham, Haidt, \& Nosek, 2009; Graham et al., 2011; Kim, Kang, \& Yun, 2012; Nilsson \& Erlandsson, 2015; Van Leeuwen \& Park, 2009; however see evidence that ideology drives moral intuitions: Hatemi, Crabtree, \& Smith, 2019). The emerging field of political neuroscience (Haas, Warren, \& Lauf, 2020; Jost, Nam, Amodio, \& Van Bavel, 2014; Nam, 2020; Smith \& Warren, 2020; Zmigrod \& Tsakiris, 2021) has even revealed differences between political liberals and conservatives in their neurobiology (e.g. Amodio, Jost, Master, \& Yee, 2007; Haas, Baker, \& Gonzalez, 2017; Kanai, Feilden, Firth, \& Rees, 2011; Nam et al., 2018; Oxley et al., 2008; Schreiber et al., 2013) and in their neural responses to affective (Carraro, Castelli, \& Macchiella, 2011; Smith, Oxley, Hibbing, Alford, \& Hibbing, 2011), facial (Vigil, 2010), and political content (Leong, Chen, Willer, \& Zaki, 2020). Although this is far from an exhaustive review, most outlooks on the literature will conclude that when politically-opposed groups are compared based on self-categorizations of ideological affiliations, psychological differences between them do emerge. 


\section{Psychological Commonalities in Ideological Thinking}

At the same time, however, when studies have taken an approach that emphasizes ideological extremity rather than purely focusing on the mission of the ideology, a more complex picture has surfaced. From a methodological standpoint, these studies often employ measurement tools that tap into continuous individual differences in ideological attachment, extremity, and partisan radicality. These investigations have concentrated on the structure of ideological adherence and have illustrated that it is fruitful to study ideological thinking in a way that is largely agnostic as to the aims of the ideology (Zmigrod et al., 2020) - this reveals remarkable psychological commonalities in ideological thinking across a variety of ideological domains.

There have been two lines of research within psychology which have revealed the striking similarities in the psychological underpinnings of ideological thinking across disparate ideological domains. The first line of research has centred on personality and motivational factors (measured via subjective self-report questionnaires) and the second has focused on the implicit cognitive factors (measured with objective neuropsychological and behavioural tasks) underlying ideological thinking.

\section{Personality Traits and Motivations}

In terms of personality and motivation, it is possible to synthesize common dispositions that predict ideological thinking across domains. Personality traits associated with reduced open-minded thinking (Pennycook, Cheyne, Koehler, \& Fugelsang, 2019), heightened sensitivity to distress and fear (for reviews see: van Prooijen \& Krouwel, 2019; van Prooijen, Krouwel, Boiten, \& Eendebak, 2015), avoidance of social risk-taking (Zmigrod, Eisenberg, Bissett, Robbins, \& Poldrack, 2020), and intolerance of uncertainty (for review see: Hogg, 2014) have been generally implicated in ideological thinking in the context of various ideological identities and groups. Another example centres around the theory that 
intergroup behaviour that avoids foreign, dissimilar others may be rooted in behavioural adaptations that protect against infection (the so-called "behavioural immune system"). Processes associated with disgust sensitivity and pathogen-avoidance have been implicated in authoritarian worldviews, outgroup derogation, and moral judgments across multiple psychological paradigms and cross-cultural ecological studies, and across multiple ideological domains (e.g. Ji, Tybur, van Vugt, 2019; Karinen, Molho, Kupfer, \& Tybur, 2019; Tybur, Cinar, Karinen, Perone, 2018; Tracy, Steckler, \& Heltzel, 2019; Tybur et al., 2016; Zmigrod, Ebert, Goetz, \& Rentfrow, 2021). Recent research centred on dogmatism measured through individuals' general receptivity to evidence and respect for credible alternative viewpoints - has shown that dogmatic individuals have highly impulsive personalities (Zmigrod et al., 2020). Impulsivity was also implicated in individuals endorsing ideological violence to protect their ingroup (Zmigrod \& Goldenberg, 2021), suggesting impulsivity contributes to ideological tendencies (Zmigrod et al., 2020). Additionally, from a motivational perspective, work on the psychology of political action has posited that motivations surrounding identity, efficacy, emotion; and morality may be core motivations for ideological action across a diversity of ideological contexts (Cichocka et al., 2018; Osborne, Jost, Becker, Badaan, \& Sibley, 2019; Pliskin, Rhurman, \& Halperin, 2020; Van Bavel \& Pereira, 2018; van Zomeren, 2016).

It is noteworthy that an immense array of personality traits have been studied in relation to one ideological domain (e.g. political conservatism), but not rigorously examined in others, making extrapolation of the psychological correlates of "ideological thinking" challenging. For instance, the role of intuitive versus analytic thinking has been examined in the context of political conservatism and religiosity (for meta-analysis: Pennycook, Ross, Koehler, \& Fugelsang, 2016), but its role in relation to dogmatism and ideological extremity has not been carefully addressed. Similarly, the cognitive science of religion has discussed 
the role of mentalizing abilities in predicting religious and paranormal beliefs (e.g. Norenzayan, Gervais, Trzesniewski, 2012; Jack, Friedman, Boyatzis, \& Taylor, 2016; van Elk \& Aleman, 2017; Gervais, 2013), but this has not been coherently linked to the mind perception literature in intergroup psychology (e.g. Hackel, Looser, \& Van Bavel, 2014; Fiske \& Neuberg, 1990). Conducting research that assesses multiple ideologies simultaneously will help structure future research on the personality antecedents of ideological orientations in a more fruitful direction, allowing delineation of what psychological processes are specific to particular ideologies and which can be evident in adherence to any powerful ideology.

\section{Cognitive Dispositions}

With respect to the cognitively-oriented research, a number of cognitive traits have been recently shown to confer susceptibility to ideological thinking (Zmigrod, 2020). Three notable examples are: (1) cognitive inflexibility, (2) impaired strategic information processing, and (3) slower perceptual evidence processing. Firstly, an emerging line of research is suggesting that a tendency towards cognitive rigidity can foster ideological rigidity. Cognitive inflexibility is operationalized in the neuropsychological literature as a difficulty with switching between modes of thinking and adapting to changing environmental contingencies (Zmigrod, 2020). Mental inflexibility has been implicated in extreme ideological identities (for review see Zmigrod, 2020) in the context of politics (Zmigrod et al., 2020), nationalism (Zmigrod, Rentfrow \& Robbins, 2018), religion (Zmigrod et al., 2019a), dogmatism (Zmigrod et al., 2019b), and a willingness to endorse violence and selfsacrifice (Zmigrod, Rentfrow, \& Robbins, 2019). Importantly, cognitive rigidity was manifest on both the extreme right and the extreme left (Zmigrod et al., 2020), suggesting that ideological extremity may be as psychologically important as the mission of the ideology. These studies quantified cognitive inflexibility with objective behavioural tests of executive 
function and perception, in which participants were asked to continuously change between mental rules and categories. Consequently, findings using behavioural experimental paradigms are not susceptible to biases of social-desirability, self-perception, and social norms that can become manifest in self-report questionnaires. This line of research illustrates that individual differences in cognitive inflexibility can confer susceptibility to ideological thinking (Zmigrod, 2020).

Furthermore, recent research examining the cognitive profiles of a range of ideological attitudes found that impairments in strategic information processing were linked to more conservative, authoritarian, nationalistic, and religious tendencies (Zmigrod et al., $2021)^{5}$. This impairment was also evidenced in individuals who were more willing to support extreme pro-group actions to protect their ingroup. These impairments were manifest in performance on executive functioning tasks associated with working memory and planning, illustrating that there are common cognitive roots to ideological thinking across a range of ideological contexts. A difficulty in planning and executing complex action sequences in basic perception may thus increase people's reliance on coherent collective dogmas that simplify the world into absolute explanations and clear behavioural prescriptions.

The study of low-level perception and cognition has further revealed that how the mind processes perceptual evidence can confer susceptibility to ideological dogmatism across a diversity of ideologies. Using drift-diffusion modelling (DDM) of trial-by-trial performance on two-forced choice tasks illustrated that slower evidence accumulation of perceptual data is linked to a dogmatic thinking style (Zmigrod et al., 2020). This suggests that nondogmatic individuals are better able to process and accumulate evidence in perceptual decision-making

\footnotetext{
${ }^{5}$ Notably, authoritarianism was measured with an assessment of people's favouring of values of conformity and obedience, and religiosity was evaluated based on people's frequency of prayer, ritual attendance, and subjective sense of religion's importance - consequently, these ideological worldviews were separate from overtly rightwing attitudes.
} 
contexts generally, and this may translate to a better ability to process evidence in ideological settings as well. Notably, these perceptual phenomena occur on the order of milliseconds and are not under conscious control. Consequently, the findings suggest that individual differences in low-level visual information processing can reveal variations in ideological thinking as well.

Finally, the analysis of perceptual decision-making processes demonstrated that response caution - a perceptual preference for accuracy over speed in tasks where both accuracy and speed are rewarded - was related to more socially conservative and nationalistic worldviews (Zmigrod et al., 2020). Cautious perceptual strategies may therefore translate into cautious (i.e. conservative) ideological beliefs. Studying the relationship between ideological attitudes and individual differences in low-level perceptual and cognitive processing can therefore help elucidate the underpinnings of ideological thinking.

\section{Conceptual and Methodological Directions}

An emergent conclusion from the observed similarities of diverse ideologies is that we should study ideological thinking and related processes under one umbrella. An appreciation of the psychological structure of ideological thinking can be empirically productive and theoretically valuable. How can this be achieved? Let us examine the directions which this emerging field can take in terms of (1) conceptual and (2) methodological future avenues.

\section{Developing a Conceptual Research Agenda}

Building on this integrative framework, we can construct a clear guiding research agenda for this burgeoning field. In particular, we can envision three major research questions that need to be addressed: (1) Antecedents: What psychological traits and experiences confer susceptibility to ideological thinking? (2) Processes: What psychological 
factors shape the intensity of ideological immersion and choice of ideology? And (3)

Consequences: What are the psychological and neurocognitive consequences of ideological engagement? Focusing and delineating research efforts along these central research questions will allow us to address the nuanced processes that confer initial susceptibility to internalising ideological doctrines, as well as the mechanisms that reinforce or dampen these effects. It will enable the field to construct comprehensive, causally-minded theories and paradigms that can be positioned on par with other major scientific endeavours. When we adopt a framework that seriously engages with the psychological phenomena that underpin political thought and action, we can formulate socially pertinent questions that address the bidirectional links between ideologies and cognition.

In order to advance an integrated psychology of ideology that taps at these questions, it is essential to collaboratively examine the psychology of religion, political psychology, moral psychology, intergroup psychology, and the study of obedience, conformity, and prejudice. This will allow us to evaluate psychological processes that have been hypothesized to be ideology-specific and to interrogate whether these are truly ideology-specific or have simply not been studied (sufficiently) in the context of other ideologies. We can then ask the essential questions: Why are some psychological traits predictive of adherence to certain ideologies and not others? And why are some psychological dispositions predictive of extremity regardless of the ideology's content? It is only through a rigorous integrative theoretical approach that we can design empirical tests that can truly begin to tap at mechanistic explanations in the psychology of ideology. Furthermore, it will allow researchers to build theories that directly address the research questions about the origins, processes, and consequences of engagement with ideological doctrines. We can thereby achieve greater precision in our mechanistic accounts of the ideological mind - arriving at 
general principles as well as nuanced trajectories that consider where, when, and why the doctrine of the ideology can shape its impact on the minds of adherents.

A multitude of excellent examples in recent research have begun separating the content and structure of ideologies, and thereby elucidated the psychological antecedents, processes, and consequences of ideological engagement. With regards to questions of the cognitive antecedents of ideology, Peterson and Iyengar (2020) found that both political liberals and political conservatives exhibit sincere motivated reasoning of misinformation, and both are influenced by moderate insincere cheerleading effects that shape their information processing of political facts. By putting into competition alternative theories of partisan information-seeking behaviour, including content-oriented and structure-based hypotheses, the authors fruitfully clarified the nature of ideological gaps in news evaluation. Another example mentioned earlier is the data-driven investigation by Zmigrod and colleagues (2021), which examined the psychological factors that predict ideological thinking in a range of ideologies. This study revealed that there are certain cognitive and personality dispositions that predict strong or dogmatic adherence to any ideology, and other psychological individual differences that are specific to particular ideologies. Hence, it is possible to elucidate the patterns of psychological commonalities and discrepancies by adopting a large-scale data-driven approach that facilitates robust comparisons between the psychological origins of different ideologies.

In relation to questions on the psychological processes of ideological cognition, recent research on ideological social action in online social networks has been able to control for both the content and extremity of messages and study these interactive effects. This approach has revealed that moral emotions such as anger and disgust proliferate on Twitter for politicians on both the left and right of the political spectrum, whereas certain forms of moral-emotional language and expression were more impactful for conservative political 
elites than for liberal elites, even after controlling for ideological extremity (Brady, Wills, Burkhart, Jost, \& Van Bavel, 2019). Similarly, when examining politically-engaged Twitter users, Boutyline and Willer (2017) found that individuals who were both more conservative and more extreme were more likely to seek out political homophily (affirmations of their views, rather than challenges to it). Consequently by empirically separating content and extremity, it is possible to identify their interacting and amplifying effects on behaviour - and consider the (online) ecology that makes these ideological behaviours possible.

Lastly, with regards to research on the consequences of ideologies on neural and cognitive functioning, Krosch and Amodio (2019) showed that framing resources in terms of scarcity disrupts neural processing of minority group faces in the context of race. Moreover, this scarcity-induced disruption to neural encoding predicted discriminatory resource allocation of white participants. This finding reveals that the way in which the brain responds to scarcity in its visual encoding of minorities can shed light on the origins of discriminatory and prejudiced behaviour in times of economic stress. Hence, context matters when minds process ingroups and outgroups (also shown by Jasko et al., 2019) and so we must develop theories that integrate contextual moderators of brain processes - such as resource levels, conflict dynamics, and stressors - when considering the psychological consequences of ideological narratives. Furthermore, recent work by Goudarzi, Pliskin, Jost, and Knowles (2020) indicates that economic system justification is related to muted emotional and physiological responses to manifestations of poverty and wealth. Ideologies can thereby serve psycho-physical functions, shaping the nervous system's responses to a variety of social stimuli. However, scientists of ideological thinking will need to tackle difficult questions about why we observe correspondences between social attitudes and cognitive structure, and what behavioural and neural mechanisms underpin these correspondences. This endeavour will involve the use of experimental paradigms, behavioural genetics, and longitudinal and 
developmental studies, in order to inform a nuanced account of how neurocognitive susceptibilities are co-opted by ideologically-prone contexts (Zmigrod, 2021).

Importantly, aiming at theoretical synthesis between ideological content and structure, and between the psychology of diverse ideological narratives, does not mean achieving absolute synchrony in how we study political, religious, and social ideologies. Rather, it propels us to develop broad paradigms that facilitate scientific coherence when we consider ideologies in tandem. Theoretical unification should not necessarily force us to draw false equivalences between ideologies (Baron \& Jost, 2019), such as between those which are used for social domination versus those promoted in the name of social equality. The key with this integrative structure-oriented approach is to empirically and theoretically test where diverse ideological movements exhibit parallels and where they differ - and through this endeavour understand who is most attracted to (certain) ideologies and why.

\section{Methodological Directions}

A key step necessary to advance a theoretically mature (and conceptually adventurous) psychology of ideology is to build appropriate, and sometimes novel, assessment tools. There are three main avenues for future methodologically-oriented research that will have a particularly fruitful impact on future studies. Firstly, it is necessary to create content-free measures of ideological attitudes and behaviour: tools that assesses ideological thinking without invoking the particular content of that ideology. Measures where the content is easily substitutable with simple alterations are also valuable, such that the structure of the questions is consistent regardless of the ideology in question. This is important in order to be able to truly compare the psychological correlates of diverse ideological orientations. This will also allow for research outside of WEIRD samples, which is especially critical in order to augment the cross-cultural and historical validity (Henrich, Heine, \& Norenzayan, 2010; 
Muthukrishna, Henrich, \& Slingerland, 2020; Roberts, Bareket-Shavit, Dollins, Goldie, \&

Mortenson, 2020) - and highlight instances of cultural specificity - of this emerging science.

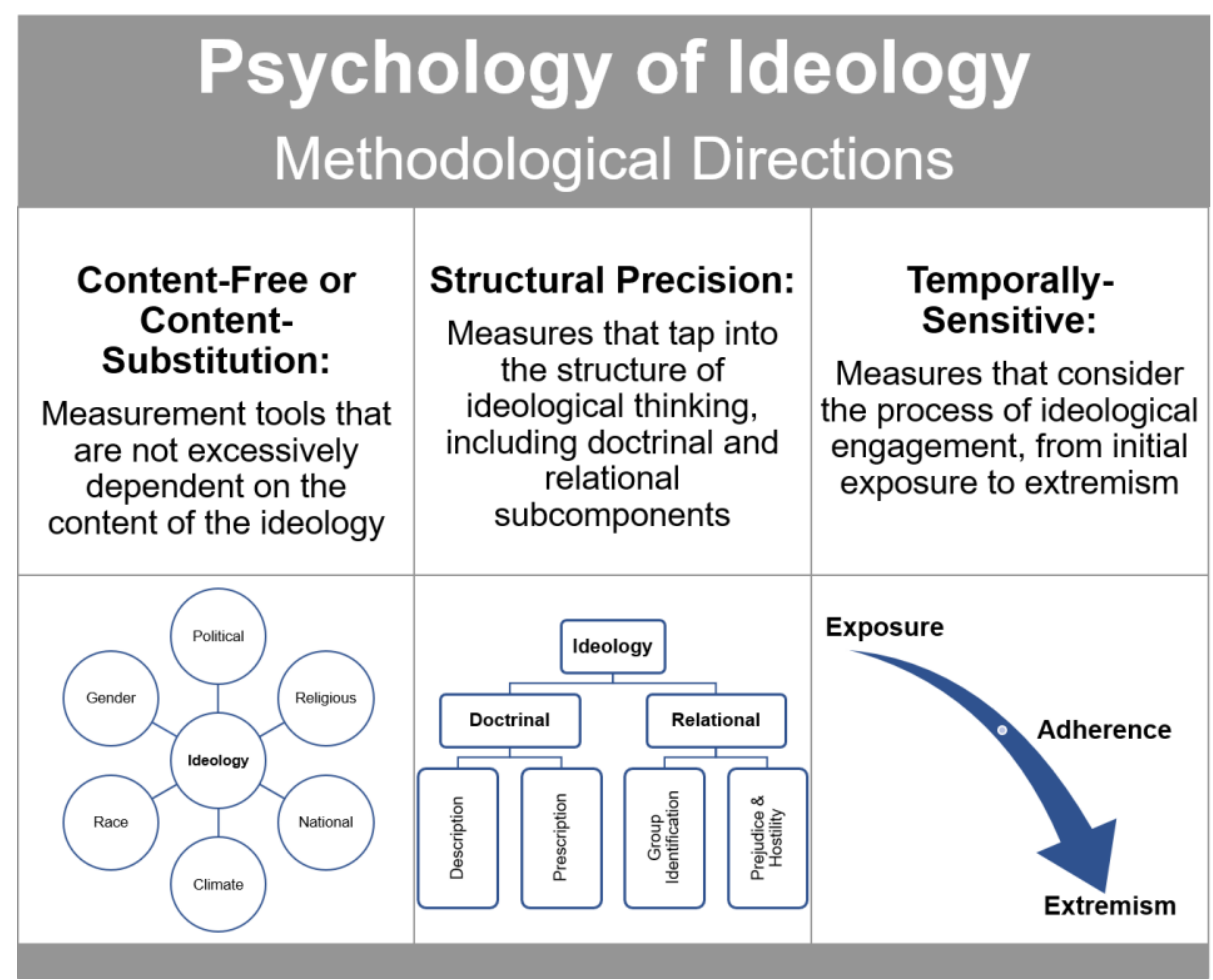

Figure 3. Methodological directions for a unified psychology of ideology.

Secondly, there is a need for measures that tap at the structure of ideological thinking, by separately quantifying the doctrinal and relational components of ideologies (see Figure 3). For instance, measuring individuals' embrace of a dogma would involve surveying their beliefs about the causes of societal conditions (tapping into the description subcomponent of the doctrine) and assessing their levels of endorsement of the dogma's prescriptions and the need to punish when there is deviance from the ideology's rules (prescription subcomponent). To evaluate the relational component, it may be necessary to measure individuals' identification and personal identity fusion with the ideological group and the extent to which they would be ready to self-sacrifice for its causes (group identification 
subcomponent). Measuring outgroup derogation would involve surveying individuals' discriminatory behavioural tendencies and their endorsement of violence against nonadherents (prejudice and hostility subcomponent). There are measures that assess how one would treat non-adherents, or one's levels of prejudice, but these are usually not incorporated into the same study design as those that assess how evidence-resistant an individual is with regards to that ideology. This precision in the assessment of the structure of ideological thinking would facilitate research of pertinent questions, such as: How do the doctrinal and relational aspects of ideological thinking emerge in tandem within an individual? How are the doctrinal and relational elements structurally related? That is, does one temporally precede the other and how do they reinforce and amplify each other? What personal and social experiences or motivations affect the emergence of each? Do the doctrinal and relational components possess separable or similar cognitive correlates? What are the real-world manifestations of the relational component without a doctrinal component (e.g. avid sports fans $^{6}$ ) or the reverse (e.g. lone suicide terrorists $\left.{ }^{7}\right)$ ? Unpacking the structure of ideological thinking through appropriate methodological tools is therefore a key next step for this line of research.

Lastly, the field needs assessment tools that address the temporal dimension of ideological engagement in order to study the whole process of ideological immersion, from exposure to adherence to extremism. Each stage between initial exposure to radical adherence and self-sacrifice is likely to have overlapping as well as unique susceptibility factors, and so we need appropriate assessment tools to evaluate individuals' position at each stage. Indeed, developmental and longitudinal studies will be necessary in order to elucidate causal links

\footnotetext{
${ }^{6}$ However, arguably some fans are also resistant to information of poor performance by their team, and so the doctrinal aspect can exist in sports group memberships as well.

7 Nonetheless, even when an individual is supposedly purely motivated by ideology, there is often the hope of social connectedness or recognition in the afterlife, and so the relational aspect can be evident here as well.
} 
and self-reinforcing loops between cognitive dispositions and ideological identity and behaviour.

Early seeds of these approaches can already be seen in recent research and can be built upon in order for the field to attain greater methodological maturity (Rollwage, Zmigrod, et al., 2019; Zmigrod \& Tsakiris, 2021). For example, a measurement tool that has grown in popularity is the identity fusion index (Jimenez et al., 2016), in which the participant is asked to move a small circle labelled "Me" in relation to a large static circle labelled with the name of the ideological group (e.g. a personally-relevant religious group, political party, or nation). The amount of overlap between the two circles and the distance between the circles can be used as a metric of personal feelings of immersion with the ideological group. The power of this measure lies in its applicability to any ideological or social group, such that the amount of identity fusion is quantifiable and translatable between ideologies. The identity fusion index has been used in the context of nationalism (Bortolini et al., 2018; Jong et al., 2015; Kapitany et al., 2019; Zmigrod, Rentfrow, \& Robbins, 2018), political partisanship (Misch, Fergusson, \& Dunham, 2018; Zmigrod, Rentfrow, \& Robbins, 2019b), resilience in the face of terror (Jong et al., 2015), and willingness to engage in extreme protest and pro-group behaviour (Kunst et al., 2018; Paredes et al., 2019; Purzycki \& Lang, 2019). The identity fusion index therefore satisfies the criterion of being easily contentsubstitutable (by altering the group label on the large circle) and by tapping into the group identification subcomponent of ideological thinking. It can also be used in longitudinal designs (e.g. Misch et al., 2018) as it involves continuous scales that capture a large range of variation in responses and can be repeated with little interference from memory of past responding.

Another attempt to create a content-free or content-substitutable measure is the OpenMinded Cognition Scale, in which the scale items can be easily adjusted to target general, 
political, or religious open-minded cognition (Price, Ottati, Wilson, \& Kim, 2015). For instance, the 6-item scale contains items such as "I am open to considering other (political/religious) viewpoints" and "I have no patience for (political/religious) arguments I disagree with". Nonetheless, recent work by Crawford, Brandt, and Germano (2018) challenges the predictive validity of the Open-Minded Cognition Scale and suggests that it may be best conceptualized as a measurement of self-perceived open-minded cognition rather than open-minded cognition itself (Crawford, Brandt, \& Germano, 2018, p. 24).

Consequently, there is still substantial room for methodological work that seeks to develop appropriate, reliable, and predictive measures that avoid social-desirability biases ${ }^{8}$ and effectively tap at the psychological elements of ideological processes.

\section{Conclusions}

As the political thinker Walter Lippmann already noted in 1922, the political environment in which humans are situated

"is altogether too big, too complex, and too fleeting for direct acquaintance. We are not equipped to deal with so much subtlety, so much variety, so many permutations and combinations. And although we have to act in that environment, we have to reconstruct it on a simpler model before we can manage it." (Lippmann, 1922/1949, p. 11).

Ideologies thereby "impose a certain character on the data of our senses before the data reach our intelligence" (Lippman, 1922/1949, p. 65) - and it is this profound mental structuring and filtering effect that renders ideological thinking an important object for rigorous investigation.

\footnotetext{
${ }^{8}$ Indeed, a pictorial measure like the Identity Fusion index helps ameliorate these kinds of biases because there aren't strong social norms regarding how "fused" one ought to be with a particular group on a continuous scale of 0-100.
} 
Given the kaleidoscopic diversity of mass movements, doctrines, and regimes that characterize human history and culture, it is urgent and paramount to isolate and define the core processes of ideological adherence, immersion, and extremism. A synthesis of the multitude of literatures that deal with this topic indicates that there are core commonalities in the substrates of adherence to ideological doctrines regardless of their content. But there are also likely to be important differences that are ideology-specific. A wholistic and integrated psychology of ideology will be able to catch these nuances and offer pegs on which to hang and identify the various psychological dispositions and processes that propel individuals to process and respond to the world in an ideological fashion. Consequently, it is valuable to cluster these behaviours and tendencies in common terms and under unified theoretical frameworks if scientific endeavours to deconstruct these phenomena are to be meaningful and applicable. An integrated psychology of ideology will allow us to more fully comprehend the susceptibility factors - and antidotes - to worldviews that are dogmatic, extreme, and hostile to dissimilar others.

This review set out to synthesize a tractable framework through which we can comprehend ideological thinking, and to demonstrate that we need to address the unfruitful balkanization of this field. A siloed field is the result of an interest in the content of ideological beliefs, such as why people believe in omnipotent supernatural forces or why they adhere to hierarchical conceptualizations of social relations. A unified field would allow us to evaluate questions about the structure of ideological thinking, and thereby also to isolate the role of an ideology's content. Both levels of analysis - the structural and the substantive can be brought to the fore, but only if we recognize and learn to quantify them effectively. To move the field forward, we must disambiguate these two levels and find ways to bring them into contact. Consequently, future studies need to carefully consider and delineate which level of analysis they are examining or neglecting. This will unfold fascinating and pertinent 
questions, such as why we observe repeated patterns of ideological indoctrination across cultures and throughout history, and why some people are susceptible to dogmatic thinking regardless of their political leanings. How are ideologies "inherited" and communicated? How malleable are the ideologies people hold? What ideologies have the most powerful cognitive impact? Through research practices that seriously consider the multitude of ideologies that have graced (and harmed) human existence, researchers will be able to examine holistically what happens to our behaviour and brains when we are inculcated with ideological mindsets. It is imperative to view ideologies (and the historical "isms" that have been made automatically equivalent to ideologies) in a critical, creative, and reflexively nondogmatic fashion.

Hence, it may be time to re-evaluate Converse's observation (quoted in the epigraph) that belief systems don't concede easily to empirical assessment. Since Converse published The Nature of Belief Systems in Mass Publics in 1964, we have come a long way in our analytic and methodological capabilities and so perhaps the psychology of ideology holds more promise and potential. Considering the domain-general elements of ideological thinking will enrich our theories, improve the sophistication of methodologies, and position us more firmly as a field that can build a fairer, more robust scientific community and set of scientific practices. A psychology of ideology thereby holds the potential of combatting the dangers of dogmatism and entrenched beliefs both within the field and in the outside world. 


\section{REFERENCES}

Adorno, T. W., Frenkel-Brunswik, E., Levinson, D. J., \& Sanford, R. N. (1950). The Authoritarian Personality. New York: Harper.

Amodio, D. M., Jost, J. T., Master, S. L., \& Yee, C. M. (2007). Neurocognitive correlates of liberalism and conservatism. Nature neuroscience, 10(10), 1246-1247.

Anderson, B. (1983). Imagined Communities: Reflections on the Origin and Spread of Nationalism. London: Verso.

Arendt, H. (1951). The Origins of Totalitarianism. Cleveland, OH: Meridian

Atran, S. (2002). In gods we trust: The evolutionary landscape of religion. Oxford University Press.

Bakker, B. N., Schumacher, G., Gothreau, C., \& Arceneaux, K. (2020). Conservatives and liberals have similar physiological responses to threats. Nature Human Behaviour, 1-9.

Baron, J., \& Jost, J. T. (2019). False equivalence: Are liberals and conservatives in the United States equally biased?. Perspectives on Psychological Science, 14(2), 292-303.

Billig, M. (1995). Banal Nationalism. Sage Publications Ltd.

Blank, J. M., Shaw, D. (2015). Does partisanship shape attitudes toward science and public policy? The case for ideology and religion. Annals of the American Academy of Political and Social Science, 658, 18-35.

Bortolini, T., Newson, M., Natividade, J. C., Vázquez, A., \& Gómez, Á. (2018). Identity fusion predicts endorsement of pro-group behaviours targeting nationality, religion, or football in Brazilian samples. British Journal of Social Psychology, 57(2), 346-366.

Boutyline, A., \& Willer, R. (2017). The social structure of political echo chambers: Variation in ideological homophily in online networks. Political Psychology, 38(3), 551-569.

Boyd, R., Gintis, H., Bowles, S., \& Richerson, P. J. (2003). The evolution of altruistic punishment. Proceedings of the National Academy of Sciences, 100(6), 3531-3535. 
Brady, W. J., Wills, J. A., Burkart, D., Jost, J. T., \& Van Bavel, J. J. (2019). An ideological asymmetry in the diffusion of moralized content on social media among political leaders. Journal of Experimental Psychology: General, 148(10), 1802.

Brandt, M. J. (2017). Predicting ideological prejudice. Psychological Science, 28(6), 713-722.

Brandt, M. J., Reyna, C., Chambers, J. R., Crawford, J. T., \& Wetherell, G. (2014). The ideological-conflict hypothesis: Intolerance among both liberals and conservatives. Current Directions in Psychological Science, 23(1), 27-34.

Campbell, A., Converse, P. E., Miller, W. E., \& Stokes, D. E. (1960). The American voter. John Wiley.

Carney, D. R., Jost, J. T., Gosling, S. D., \& Potter, J. (2008). The secret lives of liberals and conservatives: Personality profiles, interaction styles, and the things they leave behind. Political Psychology, 29(6), 807-840.

Carraro, L., Castelli, L., \& Macchiella, C. (2011). The automatic conservative: Ideologybased attentional asymmetries in the processing of valenced information. PLoS One, 6(11), e26456.

Choma, B. L., \& Hanoch, Y. (2017). Cognitive ability and authoritarianism: Understanding support for Trump and Clinton. Personality and Individual Differences, 106, 287-291.

Cichocka, A., Górska, P., Jost, J. T., Sutton, R. M., \& Bilewicz, M. (2018). What inverted U can do for your country: A curvilinear relationship between confidence in the social system and political engagement. Journal of Personality and Social Psychology, 115(5), 883-902.

Connor, W. (1994) Ethnonationalism. Princeton, NJ: Princeton University Press 
Converse, P. E. (1964). The nature of belief systems in mass publics. Ideology and discontent. Ideology and Discontent, 206-261.

Corner, J. (2001). 'Ideology': a note on conceptual salvage. Media, Culture \& Society, 23(4), 525-533.

Jost, J. T., Sterling, J., \& Stern, C. (2017). Getting closure on conservatism, or the politics of epistemic and existential motivation. In The motivation-cognition interface (pp. 56-87). Routledge.

Crawford, J., \& Brandt, M. (2018, February 7). Testing the predictive validity of the open-minded cognition scale. https://doi.org/10.31234/osf.io/v8um2

Crawford, J. T., \& Brandt, M. J. (2019). Who Is Prejudiced, and Toward Whom? The Big Five Traits and Generalized Prejudice. Personality and Social Psychology Bulletin, 45(10), 1455-1467.

Crawford, J. T., \& Brandt, M. J. (2020). Ideological (a) symmetries in prejudice and intergroup bias. Current Opinion in Behavioral Sciences, 34, 40-45.

Crawford, J. T., \& Pilanski, J. M. (2014). Political intolerance, right and left. Political Psychology, 35(6), 841-851.

Dant, T. (1991). Knowledge, Ideology, and Discourse. New York: Routledge

DeMarrais, E., Castillo, L. J., \& Earle, T. (1996). Ideology, materialization, and power strategies. Current anthropology, 37(1), 15-31.

Deary, I. J., Batty, G. D., Gale, C. R. (2008). Bright children become enlightened adults. Psychological Science, 19, 1-6.

Denzau, A. T., \& North, D. C. (1994). Shared mental models: ideologies and institutions. Kyklos, 47(1), 3-31. 
Ditto, P. H., Liu, B. S., Clark, C. J., Wojcik, S. P., Chen, E. E., Grady, R. H., ... \& Zinger, J. F. (2019). At least bias is bipartisan: A meta-analytic comparison of partisan bias in liberals and conservatives. Perspectives on Psychological Science, 14(2), 273-291

Douglas, K. M., Sutton, R. M., \& Cichocka, A. (2017). The psychology of conspiracy theories. Current directions in psychological science, 26(6), 538-542.

Dovidio, J. F., Hewstone, M., Glick, P., \& Esses, V. M. (2010). Prejudice, stereotyping and discrimination: Theoretical and empirical overview. The SAGE handbook of prejudice, stereotyping and discrimination, 3-29.

Duarte, J. L., Crawford, J. T., Stern, C., Haidt, J., Jussim, L., \& Tetlock, P. E. (2015). Political diversity will improve social psychological science 1. Behavioral and Brain Sciences, 38 .

Duckitt, J., \& Sibley, C. G. (2009). A dual-process motivational model of ideology, politics, and prejudice. Psychological Inquiry, 20(2-3), 98-109.

Eidelman, S., Crandall, C. S., Goodman, J. A., \& Blanchar, J. C. (2012). Low-effort thought promotes political conservatism. Personality and Social Psychology Bulletin, 38(6), 808-820.

Ellis, C., \& Stimson, J. A. (2012). Ideology in America. Cambridge: Cambridge University Press.

Fehr, E., \& Gächter, S. (2002). Altruistic punishment in humans. Nature, 415(6868), 137.

Fiske, S. T., \& Neuberg, S. L. (1990). A continuum of impression formation, from category-based to individuating processes: Influences of information and motivation on attention and interpretation. In Advances in experimental social psychology (Vol. 23, pp. 174). Academic Press. 
Free, L. A., \& Cantril, H. (1967). The political beliefs of Americans. New Brunswick, NJ: Rutgers University Press.

Freeden, M. (2001). Ideology-balances and projections. Reassessing Political Ideologies: The Durability of Dissent, 193-208.

Freeden, M., Sargent, L. T., \& Stears, M. (Eds.). (2013). The Oxford handbook of political ideologies. OUP Oxford.

Friedman, J. (2006). Democratic competence in normative and positive theory: Neglected implications of "the nature of belief systems in mass publics." Critical Review, 18(1-3), 1-43. https://doi.org/10.1080/08913810608443649

Frimer, J. A., Skitka, L. J., \& Motyl, M. (2017). Liberals and conservatives are similarly motivated to avoid exposure to one another's opinions. Journal of Experimental Social Psychology, 72, 1-12.

Gellner, E. (1997) Nationalism. London: Phoenix

Gerber, A. S., Huber, G. A., Doherty, D., Dowling, C. M., \& Ha, S. E. (2010). Personality and political attitudes: Relationships across issue domains and political contexts. American Political Science Review, 111-133.

Gervais, W. M. (2013). Religious cognition. In Religion, personality, and social behavior (pp. 81-105). Psychology Press.

Graham, J., Haidt, J., \& Nosek, B. A. (2009). Liberals and conservatives rely on different sets of moral foundations. Journal of personality and social psychology, 96(5), 1029.

Graham, J., Nosek, B. A., Haidt, J., Iyer, R., Koleva, S., \& Ditto, P. H. (2011). Mapping the moral domain. Journal of personality and social psychology, 101(2), 366.

Greenberg, J., \& Arndt, J. (2011). Terror management theory. Handbook of theories of social psychology, 1, 398-415. 
Greenberg, J., \& Jonas, E. (2003). Psychological Motives and Political Orientation-The Left, the Right, and the Rigid: Comment on Jost et al.(2003). Psychological Bulletin, 129(3), 376-382.

Goudarzi, S., Pliskin, R., Jost, J., \& Knowles, E. (2019). Economic System Justification Predicts Muted Emotional Responses to Inequality.

Haas, I. J., Baker, M. N., \& Gonzalez, F. J. (2017). Who can deviate from the party line? Political ideology moderates evaluation of incongruent policy positions in insula and anterior cingulate cortex. Social Justice Research, 30(4), 355-380.

Haas, I. J., Warren, C., \& Lauf, S. J. (2020). Political neuroscience: Understanding how the brain makes political decisions. In Oxford Research Encyclopedia of Politics.

Hackel, L. M., Looser, C. E., \& Van Bavel, J. J. (2014). Group membership alters the threshold for mind perception: The role of social identity, collective identification, and intergroup threat. Journal of Experimental Social Psychology, 52, 15-23.

Henrich, J., Heine, S. J., \& Norenzayan, A. (2010). Beyond WEIRD: Towards a broadbased behavioral science. Behavioral and Brain Sciences, 33(2-3), 111.

Hatemi, P. K., Crabtree, C., \& Smith, K. B. (2019). Ideology justifies morality: Political beliefs predict moral foundations. American Journal of Political Science, 63(4), 788-806.

Haslam, N. (2006). Dehumanization: An integrative review. Personality and social psychology review, 10(3), 252-264.

Haslam, S. A., \& Reicher, S. (2007). Beyond the banality of evil: Three dynamics of an interactionist social psychology of tyranny. Personality and social psychology bulletin, 33(5), 615-622.

Heaven, P. C. L., Ciarrochi, J., Leeson, P. (2011). Cognitive ability, right-wing authoritarianism, and social dominance orientation: A five-year longitudinal study amongst adolescents. Intelligence, 39, 15-21. 
Hibbing, J. R., Smith, K. B., \& Alford, J. R. (2014). Differences in negativity bias underlie variations in political ideology. Behavioral and brain sciences, 37, 297-350.

Hodson, G., Busseri, M. A. (2012). Bright minds and dark attitudes: Lower cognitive ability predicts greater prejudice through right-wing ideology and low intergroup contact. Psychological Science, 23, 187-195.

Hoffer, E. (1951). The true believer: Thoughts on the nature of movements. New York NY: HarperCollins.

Hogg, M. A. (2005). Uncertainty, social identity and ideology. Advances in group processes, 22, 203-230.

Hogg, M. A. (2014). From uncertainty to extremism: Social categorization and identity processes. Current Directions in Psychological Science, 23(5), 338-342.

Holbig, H. (2013). Ideology after the end of ideology. China and the quest for autocratic legitimation. Democratization, 20(1), 61-81.

Inbar, Y., \& Lammers, J. (2012). Political diversity in social and personality psychology. Perspectives on Psychological Science, 7(5), 496-503. doi:10.1177/1745691612448792

Jack, A. I., Friedman, J. P., Boyatzis, R. E., \& Taylor, S. N. (2016). Why do you believe in God? Relationships between religious belief, analytic thinking, mentalizing and moral concern. PloS one, 11(3), e0149989.

Jasko, K., Webber, D., Kruglanski, A. W., Gelfand, M., Taufiqurrohman, M., Hettiarachchi, M., \& Gunaratna, R. (2019). Social context moderates the effects of quest for significance on violent extremism. Journal of personality and social psychology.

Ji, T., Tybur, J. M., \& van Vugt, M. (2019). Generalized or Origin-Specific Out-Group Prejudice?: The Role of Temporary and Chronic Pathogen-Avoidance Motivation in Intergroup Relations. Evolutionary Psychology, 17(1), 1474704919826851. 
Jimenez, J., Gomez, A., Buhrmester, M. D., Vázquez, A., Whitehouse, H., \& Swann, W. B. (2016). The dynamic identity fusion index: A new continuous measure of identity fusion for web-based questionnaires. Social Science Computer Review, 34(2), 215-228.

Johnson, S. B., Riis, J. L., \& Noble, K. G. (2016). State of the art review: poverty and the developing brain. Pediatrics, 137(4), e20153075.

Jong, J., Whitehouse, H., Kavanagh, C., \& Lane, J. (2015). Shared negative experiences lead to identity fusion via personal reflection. PloS one, 10(12), e0145611.

Jost, J. T. (2017). Ideological asymmetries and the essence of political psychology. Political Psychology, 38(2), 167-208.

Jost, J. T., \& Amodio, D. M. (2012). Political ideology as motivated social cognition: Behavioral and neuroscientific evidence. Motivation and Emotion, 36(1), 55-64.

Jost, J. T., Federico, C. M., \& Napier, J. L. (2009). Political ideology: Its structure, functions, and elective affinities. Annual review of psychology, 60, 307-337.

Jost, J. T., Glaser, J., Kruglanski, A. W., \& Sulloway, F. J. (2003). Political conservatism as motivated social cognition. Psychological bulletin, 129(3), 339.

Jost, J. T., Nosek, B. A., \& Gosling, S. D. (2008). Ideology: Its resurgence in social, personality, and political psychology. Perspectives on Psychological Science, 3(2), 126-136.

Jost, J. T., Sterling, J., Stern, C. (2018). Getting closure on conservatism, or the politics of epistemic and existential motivation. In Kopetz, C. E., Fishbach, A. (Eds.), The motivation-cognition interface: From the lab to the real world: A Festschrift in honor of Arie W. Kruglanski (pp. 56-87). New York, NY: Routledge.

Kanai, R., Feilden, T., Firth, C., \& Rees, G. (2011). Political orientations are correlated with brain structure in young adults. Current Biology, 21(8), 677-680. 
Kapitány, R., Kavanagh, C., Buhrmester, M. D., Newson, M., \& Whitehouse, H. (2019). Ritual, identity fusion, and the inauguration of president Trump: a pseudo-experiment of ritual modes theory. Self and Identity, 1-31.

Karinen, A. K., Molho, C., Kupfer, T. R., \& Tybur, J. M. (2019). Disgust sensitivity and opposition to immigration: Does contact avoidance or resistance to foreign norms explain the relationship?. Journal of Experimental Social Psychology, 84, 103817.

Kerlinger, F. N. (1984). Liberalism and conservatism: The nature and structure of social attitudes (Vol. 1). Lawrence Erlbaum Assoc Incorporated.

Kim, K. R., Kang, J. S., \& Yun, S. (2012). Moral intuitions and political orientation: Similarities and differences between South Korea and the United States. Psychological Reports, 111(1), 173-185.

Krosch, A. R., \& Amodio, D. M. (2019). Scarcity disrupts the neural encoding of Black faces: A socioperceptual pathway to discrimination. Journal of personality and social psychology, 117(5), 859 .

Kruglanski, A. W., Gelfand, M. J., Bélanger, J. J., Sheveland, A., Hetiarachchi, M., \& Gunaratna, R. (2014). The psychology of radicalization and deradicalization: How significance quest impacts violent extremism. Political Psychology, 35, 69-93.

Kunst, J. R., Boos, B., Kimel, S. Y., Obaidi, M., Shani, M., \& Thomsen, L. (2018). Engaging in extreme activism in support of others' political struggles: The role of politically motivated fusion with out-groups. PloS one, 13(1), e0190639.

Lawson, G. (2019). Anatomies of Revolution. Cambridge University Press.

Leong, Y. C., Chen, J., Willer, R., \& Zaki, J. (2020). Conservative and liberal attitudes drive polarized neural responses to political content. Proceedings of the National Academy of Sciences, 117(44), 27731-27739. 
Lewandowsky, S., Oberauer, K. (2016). Motivated rejection of science. Current Directions in Psychological Science, 25, 217-222.

Liuzza, M. T., Lindholm, T., Hawley, C. B., Gustafsson Sendén, M., Ekström, I., Olsson, M. J., \& Olofsson, J. K. (2018). Body odour disgust sensitivity predicts authoritarian attitudes. Royal Society open science, 5(2), 171091.

Malešević, S. (2002) Ideology, Legitimacy and the New State: Yugoslavia, Serbia and Croatia. London: Frank Cass.

Malešević, S. (2006). Identity as ideology: Understanding ethnicity and nationalism. Springer.

Malešević, S. (2011). The chimera of national identity. Nations and Nationalism, 17(2), 272-290.

Malka, A., \& Lelkes, Y. (2010). More than ideology: Conservative-liberal identity receptivity to political cues. Social Justice Research, 23(2), 156-188.

Marx, K. \& Friedrich, E. (1939). The German Ideology. New York: International Publishers, Inc

Mani, A., Mullainathan, S., Shafir, E., \& Zhao, J. (2013). Poverty impedes cognitive function. science, 341(6149), 976-980.

Mavor, K. I., Louis, W. R., \& Sibley, C. G. (2010). A bias-corrected exploratory and confirmatory factor analysis of rightwing authoritarianism: Support for a 3-factor structure. Personality and Individual Differences, 48, 28-33. doi:10.1016/j.paid.2009.08.006

Miller, J. M., Saunders, K. L., Farhart, C. E. (2016). Conspiracy endorsement as motivated reasoning: The moderating roles of political knowledge and trust. American Journal of Political Science, 60, 824-844 
Misch, A., Fergusson, G., \& Dunham, Y. (2018). Temporal dynamics of partisan identity fusion and prosociality during the 2016 US presidential election. Self and Identity, 17(5), $531-548$.

Muthukrishna, M., Henrich, J., \& Slingerland, E. (2020). Psychology as a historical science. Annual Review of Psychology, 72.

Nam, H. H. (2020). Neuroscientific approaches to the study of system justification. Current Opinion in Behavioral Sciences, 34, 205-210.

Nam, H. H., Jost, J. T., Kaggen, L., Campbell-Meiklejohn, D., \& Van Bavel, J. J. (2018). Amygdala structure and the tendency to regard the social system as legitimate and desirable. Nature Human Behaviour, 2(2), 133.

Nilsson, A., \& Erlandsson, A. (2015). The Moral Foundations taxonomy: Structural validity and relation to political ideology in Sweden. Personality and Individual Differences, 76, 28-32.

Nilsson, A., \& Jost, J. T. (2020). The authoritarian-conservatism nexus. Current Opinion in Behavioral Sciences, 34, 148-154.

Norenzayan, A. (2013). Big gods: How religion transformed cooperation and conflict. Princeton University Press.

Norenzayan, A., Gervais, W. M., \& Trzesniewski, K. H. (2012). Mentalizing deficits constrain belief in a personal God. PloS one, 7(5), e36880.

Onraet, E., Van Hiel, A., Dhont, K., Hodson, G., Schittekatte, M., DePauw, W. (2015). The association of cognitive ability with right-wing ideological attitudes and prejudice: A meta-analytic review. European Journal of Personality, 29, 599-621.

Osborne, D., Jost, J. T., Becker, J. C., Badaan, V., \& Sibley, C. G. (2019). Protesting to challenge or defend the system? A system justification perspective on collective action. European Journal of Social Psychology, 49(2), 244-269. 
Oxley, D. R., Smith, K. B., Alford, J. R., Hibbing, M. V., Miller, J. L., Scalora, M., ... \& Hibbing, J. R. (2008). Political attitudes vary with physiological traits. Science, 321(5896), 1667-1670.

Paredes, B., Santos, D., Briñol, P., Gómez, Á., \& Petty, R. E. (2019). The role of metacognitive certainty on the relationship between identity fusion and endorsement of extreme pro-group behavior. Self and Identity, 1-20.

Pennycook, G., \& Rand, D. G. (2020). Who falls for fake news? The roles of bullshit receptivity, overclaiming, familiarity, and analytic thinking. Journal of personality, $88(2)$, 185-200.

Pennycook, G., Ross, R. M., Koehler, D. J., \& Fugelsang, J. A. (2016). Atheists and agnostics are more reflective than religious believers: Four empirical studies and a metaanalysis. PloS one, 11(4), e0153039.

Pennycook, G., Cheyne, J. A., Koehler, D., \& Fugelsang, J. A. (2019). On the belief that beliefs should change according to evidence: Implications for conspiratorial, moral, paranormal, political, religious, and science beliefs. https://doi.org/10.31234/osf.io/a7k96

Peterson, E. \& Iyengar, S. (2020). Partisan Gaps in Political Information and Information-Seeking Behavior: Motivated Reasoning or Cheerleading?. American Journal of Political Science. https://doi.org/10.1111/ajps.12535

Pfattheicher, S., Schindler, S. (2016). Misperceiving bullshit as profound is associated with favorable views of Cruz, Rubio, Trump and conservatism. PLOS ONE, 11, Article e0153419

Phillips, J., \& Cushman, F. (2017). Morality constrains the default representation of what is possible. Proceedings of the National Academy of Sciences, 114(18), 4649-4654.

Phillips, J., \& Knobe, J. (2018). The psychological representation of modality. Mind \& Language, 33(1), 65-94. 
Phillips, J., Morris, A., \& Cushman, F. (2019). How we know what not to think. Trends in cognitive sciences, 23(12), 1026-1040.

Platt, G. M., \& Williams, R. H. (2002). Ideological language and social movement mobilization: A sociolinguistic analysis of segregationists' ideologies. Sociological Theory, 20(3), 328-359.

Pliskin, R., Ruhrman, A., \& Halperin, E. (2020). Proposing a multi-dimensional, contextsensitive approach to the study of ideological (a) symmetry in emotion. Current Opinion in Behavioral Sciences, 34, 75-80.

Price, E., Ottati, V., Wilson, C., \& Kim, S. (2015). Open-minded cognition. Personality and Social Psychology Bulletin, 41(11), 1488-1504.

Purzycki, B. G., \& Lang, M. (2019). Identity fusion, outgroup relations, and sacrifice: a cross-cultural test. Cognition, 186, 1-6.

Reicher, S., \& Haslam, S. A. (2011). After shock? Towards a social identity explanation of the Milgram 'obedience' studies. British Journal of Social Psychology, 50(1), 163-169.

Rhee, J. J., Schein, C., \& Bastian, B. (2019). The what, how, and why of moralization: A review of current definitions, methods, and evidence in moralization research. Social and Personality Psychology Compass.

Roberts, S. O., Bareket-Shavit, C., Dollins, F. A., Goldie, P. D., \& Mortenson, E. (2020). Racial inequality in psychological research: Trends of the past and recommendations for the future. Perspectives on psychological science, 15(6), 1295-1309.

Rollwage, M., Zmigrod, L., de-Wit, L., Dolan, R. J., \& Fleming, S. M. (2019). What underlies political polarization? A manifesto for computational political psychology. Trends in cognitive sciences, 23(10), 820-822.

Rorty, R. (1993). Feminism, ideology, and deconstruction: A pragmatist view. Hypatia, 8(2), 96-103. 
Rozin, P. (1999). The process of moralization. Psychological Science, 10(3), 218-221.

Sandi, C. (2013). Stress and cognition. Wiley Interdisciplinary Reviews: Cognitive Science, 4(3), 245-261.

Schreiber, D., Fonzo, G., Simmons, A. N., Dawes, C. T., Flagan, T., Fowler, J. H., \& Paulus, M. P. (2013). Red brain, blue brain: Evaluative processes differ in Democrats and Republicans. PLoS one, 8(2), e52970.

Shils, E. (1958). Ideology and civility: on the politics of the intellectual. Sewanee Review, 66, 450-480. Retrieved from http://www.jstor.org/stable/27538749

Shils, E. A., \& Janowitz, M. (1948). Cohesion and disintegration in the Wehrmacht in World War II. Public Opinion Quarterly, 12(2), 280-315.

Smith, K. B., Oxley, D., Hibbing, M. V., Alford, J. R., \& Hibbing, J. R. (2011). Disgust sensitivity and the neurophysiology of left-right political orientations. PloS one, 6(10), e25552.

Smith, K. B., \& Warren, C. (2020). Physiology predicts ideology. Or does it? The current state of political psychophysiology research. Current Opinion in Behavioral Sciences, 34, 8893.

Shtulman, A., \& Tong, L. (2013). Cognitive parallels between moral judgment and modal judgment. Psychonomic bulletin \& review, 20(6), 1327-1335.

Shtulman, A., \& Phillips, J. (2018). Differentiating "could" from "should": Developmental changes in modal cognition. Journal of Experimental Child Psychology, 165, 161-182.

Sterling, J. L., Jost, J. T., Pennycook, G. (2016). Are neoliberals more susceptible to bullshit? Judgment and Decision Making, 11, 352-360.

Stråth, B. (2013). Ideology and conceptual history. The Oxford Handbook of Political Ideologies, 1, 15-36. 
Swann Jr, W. B., Gómez, Á., Dovidio, J. F., Hart, S., \& Jetten, J. (2010a). Dying and killing for one's group: Identity fusion moderates responses to intergroup versions of the trolley problem. Psychological Science, 21(8), 1176-1183.

Swann Jr, W.B., Gómez, A., Huici, C., Morales, J., \& Hixon, J.G. (2010b). Identity fusion and self-sacrifice: Arousal as a catalyst of pro-group fighting, dying, and helping behavior. Journal of personality and social psychology, 99(5), 824-841.

Tracy, J. L., Steckler, C. M., \& Heltzel, G. (2019). The physiological basis of psychological disgust and moral judgments. Journal of personality and social psychology, 116(1), 15.

Tullett, A. M., Hart, W. P., Feinberg, M., Fetterman, Z. J., Gottlieb, S. (2016). Is ideology the enemy of inquiry? Examining the link between political orientation and lack of interest in novel data. Journal of Research in Personality, 63, 123-132.

Tybur, J. M., Çınar, Ç., Karinen, A. K., \& Perone, P. (2018). Why do people vary in disgust?. Philosophical Transactions of the Royal Society B: Biological Sciences, 373(1751), 20170204.

Tybur, J. M., Inbar, Y., Aarøe, L., Barclay, P., Barlow, F. K., De Barra, M., ... \& Consedine, N. S. (2016). Parasite stress and pathogen avoidance relate to distinct dimensions of political ideology across 30 nations. Proceedings of the National Academy of Sciences, 113(44), 12408-12413.

Useem, B. (1998). Breakdown theories of collective action. Annual review of sociology, 24(1), 215-238.

Van Bavel, J. J., \& Pereira, A. (2018). The Partisan Brain: An Identity-Based Model of Political Belief. Trends in Cognitive Sciences, 22(3), 213-224.

Van Dijk, T. A. (2006). Ideology and discourse analysis. Journal of political ideologies, 11(2), 115-140. 
Van Elk, M., \& Aleman, A. (2017). Brain mechanisms in religion and spirituality: An integrative predictive processing framework. Neuroscience \& Biobehavioral Reviews, 73, 359-378.

van Prooijen, J. W., \& Krouwel, A. P. (2019). Psychological features of extreme political ideologies. Current Directions in Psychological Science, 28(2), 159-163.

van Prooijen, J. W., Krouwel, A. P., Boiten, M., \& Eendebak, L. (2015). Fear among the extremes: How political ideology predicts negative emotions and outgroup derogation. Personality and social psychology bulletin, 41(4), 485-497.

van Prooijen, J. W., \& Van Vugt, M. (2018). Conspiracy theories: Evolved functions and psychological mechanisms. Perspectives on psychological science, 13(6), 770-788.

van Zomeren, M. (2016). Building a Tower of Babel? Integrating core motivations and features of social structure into the political psychology of political action. Political Psychology, 37, 87-114.

Van Zomeren, M., Postmes, T., \& Spears, R. (2008). Toward an integrative social identity model of collective action: A quantitative research synthesis of three sociopsychological perspectives. Psychological bulletin, 134(4), 504.

Vigil, J. M. (2010). Political leanings vary with facial expression processing and psychosocial functioning. Group Processes \& Intergroup Relations, 13(5), 547-558.

von Hippel, W., \& Buss, D. M. (2017). Do ideological driven scientific agendas impede understanding and acceptance of evolutionary principles in social psychology? In J.

T. Crawford \& L. Jussim (Eds.), The politics of social psychology (pp. 7-25). New York: Psychology Press.

Walder, A. G. (2009). Political sociology and social movements. Annual review of sociology, 35, 393-412. 
Washburn, A. N., \& Skitka, L. J. (2018). Science denial across the political divide: Liberals and conservatives are similarly motivated to deny attitude-inconsistent science. Social Psychological and Personality Science, 9(8), 972-980.

Whitehouse, H., \& Lanman, J.A. (2014). The ties that bind us: Ritual, fusion, and identification. Current Anthropology, 55(6), 674-695.

Whitehouse, H., McQuinn, B., Buhrmester, M., \& Swann, W.B. (2014). Brothers in Arms: Libyan revolutionaries bond like family. Proceedings of the National Academy of Sciences, 111(50), 17783-17785.

Williams, R. (1977). Marxism and literature (Vol. 392). Oxford Paperbacks.

Yilmaz, O., Saribay, S. A. (2017). The relationship between cognitive style and political orientation depends on the measures used. Judgment and Decision Making, 12, 140-147.

Zmigrod, L. (2020). The role of cognitive rigidity in political ideologies: theory, evidence, and future directions. Current Opinion in Behavioral Sciences, 34, 34-39.

Zmigrod, L. (2021). A Neurocognitive Model of Ideological Thinking. Politics and the Life Sciences.

Zmigrod, L., Ebert, T., Goetz, F., \& Rentfrow, P.J. (2020). The Psychological and Sociopolitical Consequences of Infectious Diseases. Journal of Social and Political Psychology. https://doi.org/10.31234/osf.io/84qcm

Zmigrod, L., Eisenberg, I.W., Bissett, P., Robbins, T.W., \& Poldrack, R. (2020). A DataDriven Analysis of the Cognitive and Perceptual Attributes of Ideological Attitudes. Philosophical Transactions of the Royal Society B: Biological Sciences. 376: 20200424. Zmigrod, L. \& Goldenberg, A. (2021). Cognition and Emotion in Extreme Political Action: Individual Differences and Dynamic Interactions. Current Directions in Psychological Science. 
Zmigrod, L., Rentfrow, P. J., \& Robbins, T. W. (2018). Cognitive underpinnings of nationalistic ideology in the context of Brexit. Proceedings of the National Academy of Sciences, 115(19), E4532-E4540.

Zmigrod, L., Rentfrow, P. J., \& Robbins, T. W. (2019). Cognitive inflexibility predicts extremist attitudes. Frontiers in psychology, 10, 989.

Zmigrod, L., Rentfrow, P. J., \& Robbins, T. W. (2020). The partisan mind: Is extreme political partisanship related to cognitive inflexibility?. Journal of Experimental Psychology: General, 149(3), 407-418.

Zmigrod, L., Rentfrow, P. J., Zmigrod, S., \& Robbins, T. W. (2019a). Cognitive flexibility and religious disbelief. Psychological research, 83(8), 1749-1759.

Zmigrod, L. \& Tsakiris, M. (2021). Computational and Neurocognitive Approaches to the Political Brain: Key Insights and Future Avenues for Political Neuroscience. Philosophical Transactions of the Royal Society B: Biological Sciences. 20200130

Zmigrod, L., Zmigrod, S., Rentfrow, P. J., \& Robbins, T. W. (2019b). The psychological roots of intellectual humility: the role of intelligence and cognitive flexibility. Personality and Individual Differences, 141, 200-208.

\footnotetext{
${ }^{\mathrm{i}}$ The identification of dogma and identity markers as tools of ideological indoctrination approximately map on to Malesevic's (2006) distinction between normative and operative ideologies, where the normative ideology entails the central pillars of the value system, including views on the structure of past, present, and future of the society and what relationships between people and groups are taking place or ought to be in order to change or preserve them. The operative ideology is how the ideology operates in daily routines.

ii These two components map on roughly (but not exactly) to a distinction made in political science between issue-based (operational) political ideology and identity-based (symbolic) ideology (Ellis \& Stimson, 2012; Mason, 2018). Issue-based (operational) ideology can be thought of as the component of political ideologies concerned with policy attitudes (Free \& Cantril, 1967). Identity-based (symbolic) ideology reflects the social connection to groups that hold particular ideological labels, such as "liberal" and "conservative" (Levitin \& Miller, 1979). The difference is that the doctrinal component here is not merely about issues - it is about the embrace of an overarching dogma, and the relational component is not purely about identification with labels - it is about intergroup orientations that dictate how adherents and non-adherents are treated. The components here are therefore not designed to align with existing political systems because these are meant to be broader than the practice of politics.
} 